\title{
Electrocarboxylation: towards sustainable and efficient synthesis of valuable carboxylic acids
}

\author{
Roman Matthessen ${ }^{1}$, Jan Fransaer ${ }^{2}$, Koen Binnemans ${ }^{3}$ and Dirk E. De Vos ${ }^{* 1}$
}

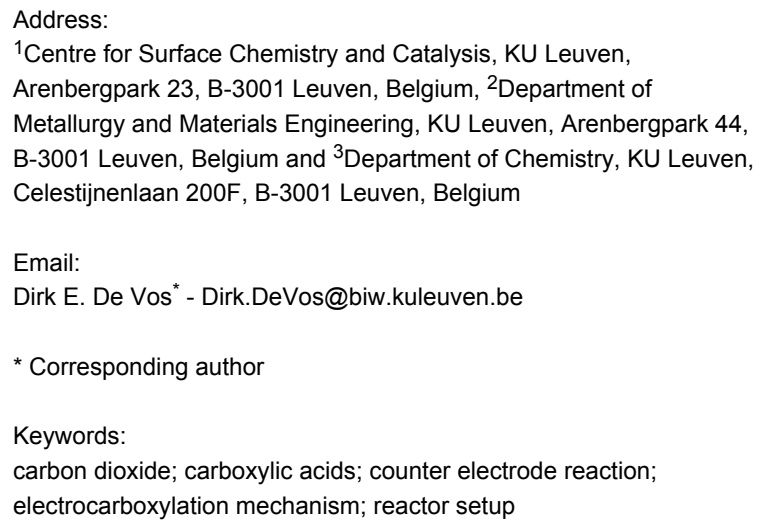

\author{
Beilstein J. Org. Chem. 2014, 10, 2484-2500. \\ doi:10.3762/bjoc. 10.260 \\ Received: 30 April 2014 \\ Accepted: 10 October 2014 \\ Published: 27 October 2014 \\ This article is part of the Thematic Series " $\mathrm{CO}_{2}$ Chemistry". \\ Guest Editors: W. Leitner and T. E. Müller
}

(c) 2014 Matthessen et al; licensee Beilstein-Institut.

License and terms: see end of document.

\begin{abstract}
The near-unlimited availability of $\mathrm{CO}_{2}$ has stimulated a growing research effort in creating value-added products from this greenhouse gas. This paper presents the trends on the most important methods used in the electrochemical synthesis of carboxylic acids from carbon dioxide. An overview is given of different substrate groups which form carboxylic acids upon $\mathrm{CO}_{2}$ fixation, including mechanistic considerations. While most work focuses on the electrocarboxylation of substrates with sacrificial anodes, this review considers the possibilities and challenges of implementing other synthetic methodologies. In view of potential industrial application, the choice of reactor setup, electrode type and reaction pathway has a large influence on the sustainability and efficiency of the process.
\end{abstract}

\section{Introduction}

\section{Carbon dioxide recycling}

Implementing sustainable, resource-efficient chemical processes to meet the world's growing demand for energy and chemicals is one of today's major challenges. Depletion of fossil resources and the ongoing increase of atmospheric carbon dioxide levels urge to investigate alternative pathways to close the carbon cycle. The use of carbon dioxide as chemical feedstock is a logical strategy for this purpose, creating economical benefit from its capture. At the moment, only a very minor fraction

$(<1 \%)$ of anthropogenic $\mathrm{CO}_{2}$ emissions is actually used [1]. As an end product of combustion, $\mathrm{CO}_{2}$ has a high thermodynamic stability $\left(\Delta G_{\mathrm{f}}{ }^{\circ}=-396 \mathrm{~kJ} / \mathrm{mol}\right)$, often demanding for an energy intensive activation. The hydrogenation of $\mathrm{CO}_{2}$ to methane for example is an industrial process which requires high temperatures and pressures to activate $\mathrm{CO}_{2}$ [2,3]. Efficient chemical incorporation of $\mathrm{CO}_{2}$ is limited to rather reactive substrates, like epoxides [4-6] and amines [7-9] to produce cyclic carbonates 
and carbamates, respectively, and even then, elevated reaction temperatures and/or complex catalyst systems are sometimes required. Urea is the main industrial product for which $\mathrm{CO}_{2}$ is applied as a $\mathrm{C}_{1}$ building block in a reaction with ammonia, still requiring pressures around 200 bar to drive the equilibrium to acceptable yields $[10,11]$. Another important end product of $\mathrm{CO}_{2}$ are inorganic carbonates, like $\mathrm{CaCO}_{3}$, produced by fast reaction with metal hydroxides [12]. Carboxylic acids are an interesting class of products, as important intermediates in the synthesis of polymers and pharmaceuticals. Hydroxybenzoic acids are among the few chemicals that are industrially produced from $\mathrm{CO}_{2}$, via the Kolbe-Schmidt reaction at high temperatures and $\mathrm{CO}_{2}$ pressures [13-15]. Sodium phenolate is selectively converted to salicylic acid, a precursor of Aspirin, while potassium phenolate exclusively yields $p$-hydroxybenzoic acid, used in polyester synthesis (Scheme 1) [16-20].

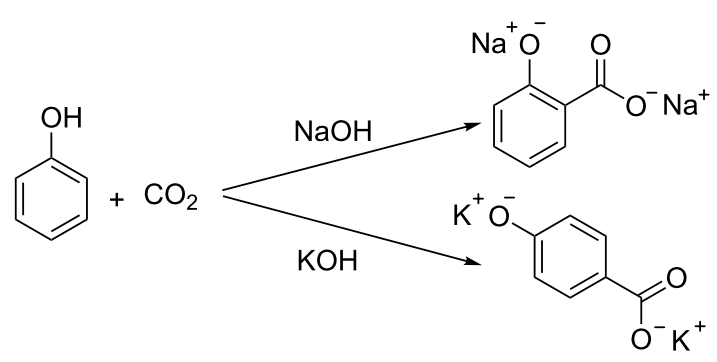

Scheme 1: Synthesis of salicylic acid and $p$-hydroxybenzoic acid via Kolbe-Schmidt reaction [16-20].

In order to generate carboxylic acids from $\mathrm{CO}_{2}$ under relatively mild conditions, reactive organometallic nucleophiles such as Grignard reagents can be used, generating a large amount of waste [21-24]. Electroreduction of $\mathrm{CO}_{2}$ can be a worthy alternative for these dangerous energy-intensive processes, replacing toxic or hazardous reducing agents by clean electrons. In this case, the high thermodynamic stability of $\mathrm{CO}_{2}$ is by-passed by a simple one-electron reduction at an electrode, leading to in situ generation of reactive intermediates. Often, room temperature conditions are sufficient, considering that the energy of the electrons is determined by the applied voltage [25]. Since the electroreduction takes place on a cathode surface, the need for complex homogeneous organometallic catalysts is minimized. Furthermore, electricity will be increasingly of renewable origin in the future, making organic electrosynthesis a promising technology for environmentally friendly chemical processes [26]. The electroreduction of $\mathrm{CO}_{2}$ can be applied for the synthesis of fuels like formic acid [27], methanol [28] or methane [29] via two-, six- and eight-electron reductions, respectively (Scheme 2). This way electric energy from periodic sustainable origin, like solar or wind energy, can be stored [30].

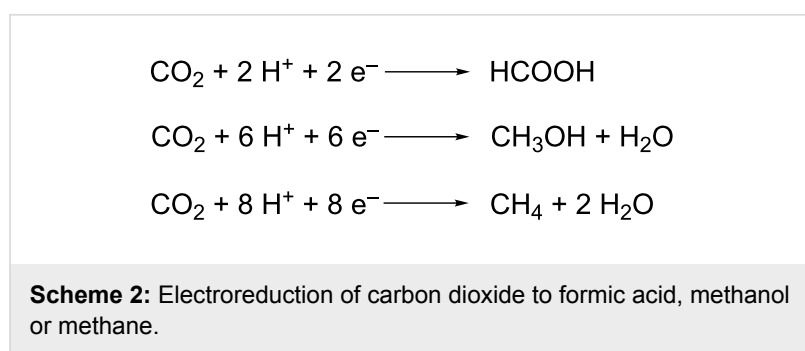

\section{Review}

In this review, the focus will be on another approach, in which $\mathrm{CO}_{2}$ is fixed in organic chemicals by means of an energy-efficient reduction process to produce valuable carboxylic acids. This methodology requires only one or two electrons per $\mathrm{CO}_{2}$ molecule, as shown in Scheme 3 for olefins, with the $\mathrm{C}-\mathrm{C}$ bond formation highlighted in bold.

$$
\mathrm{R}^{1}=m_{\mathrm{R}^{2}}+\mathrm{CO}_{2}+2 \mathrm{H}^{+}+2 \mathrm{e}^{-} \longrightarrow \mathrm{R}^{2}+2 \mathrm{CO}_{2}+2 \mathrm{H}^{+}+2 \mathrm{e}^{-} \longrightarrow \mathrm{R}_{\mathrm{O}}^{1}
$$

Scheme 3: Electrochemical fixation of $\mathrm{CO}_{2}$ in olefins.

\section{Industrial organic electrosynthesis}

The chemical industry is devoting increasing research efforts to the field of organic electrosynthesis [31]. An extended series of electro-organic processes have already been implemented on an industrial scale, like for example the electrohydrodimerisation of acrylonitrile (Scheme 4) [32], or the production of $p$-methoxybenzaldehyde [33].

2<smiles>C=CC#[N+][C+][PH2+]CC</smiles>

Scheme 4: Electrohydrodimerisation of acrylonitrile to adiponitrile [32].

Another interesting industrial process is the simultaneous production of phthalide and tert-butylbenzaldehyde dimethylacetal from dimethyl phthalate and tert-butyltoluene, respectively (Scheme 5). After separation, by distillation and precipitation, both products can be used in the production of pesticides [34]. This is an example of a paired electrosynthesis, in which the anodic and cathodic reactions simultaneously form compounds that are valuable. This way a combined electrochemical yield, i.e., the fraction of supplied current going to the desired reaction, is achieved, reducing energy consumption and reaction 
time. This methodology is very environmentally friendly since there is no generation of toxic wastes, electrical current is used more efficiently and a high atom economy is achievable [35]. The latter being the fraction of the molecular mass of all reactants which is transferred to the desired product(s). In Scheme 5, the total atom efficiency is $100 \%$ and the electrochemical yield reaches $180 \%$ [34].

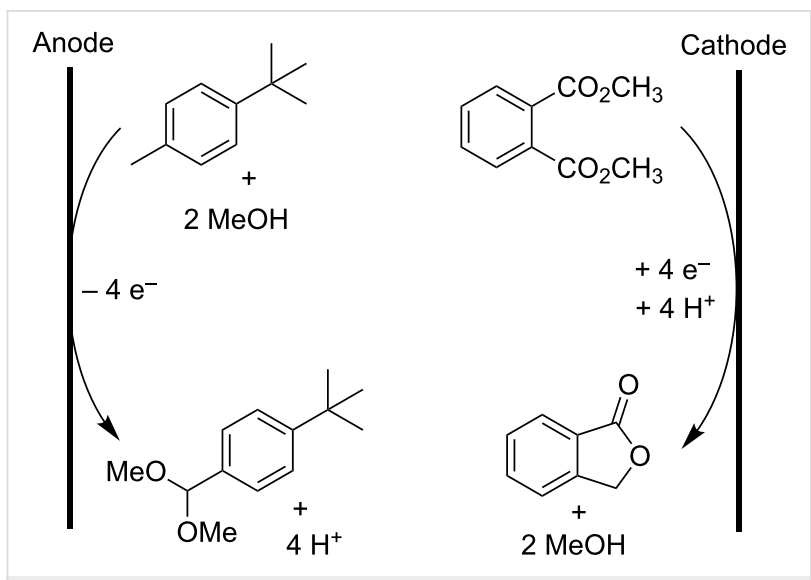

Scheme 5: Parallel paired electrosynthesis of phthalide and tert-butylbenzaldehyde dimethylacetal [34].

Moreover, numerous pilot scale processes have been demonstrated like the electrohydrodimerization of formaldehyde to ethylene glycol [36] or the production of glyoxylic acid [37]. The most important reasons for this raised interest are the higher energy efficiency compared to traditional thermochemical processes, the use of less expensive starting materials, less aggressive reaction conditions, fewer processing steps and the discovery of unique synthesis routes [31].
Despite numerous publications and patents in the field of $\mathrm{CO}_{2}$ electroreduction, no industrial processes are known in which $\mathrm{CO}_{2}$ is electrochemically incorporated in organic chemicals producing carboxylic acids. This review will give an overview of various types of electrocarboxylation procedures bearing in mind the requirements for future industrial application. Besides the identification of a profitable market for the product, minimized process costs are the major requirement for potential large scale implementation. Some parameters that influence these costs are current efficiency, reactor design, electrode material and reactant costs.

\section{Electrocarboxylation setups}

All electrochemical processes involve an anodic and cathodic reaction in order to close the electron cycle. Electrons supplied at the cathode must emerge from an oxidation reaction occurring at the anode (Scheme 6). The electrochemical system should be optimized to prevent unfavorable interference between both reactions, since such conflicts cause electric current to be lost and lead to a decrease in faradaic efficiency. Electrocarboxylation, the electrochemical fixation of carbon dioxide in organic chemicals, involves the electroreduction of carbon dioxide and/or an organic substrate. For olefins, alkynes, carbonyl compounds, imines and organic halides, this leads to the formation of carboxylate anions. A counter cation is required in order to obtain a stable reaction product and an anodic reaction is necessary to complete the electron cycle. The anodic generation of this counter cation has been a challenging and important point of discussion for many years, as will become clear further in this review. An overview of different possible setups for obtaining carboxylic acids is given in Scheme 6.
Anodic reaction:

(a)

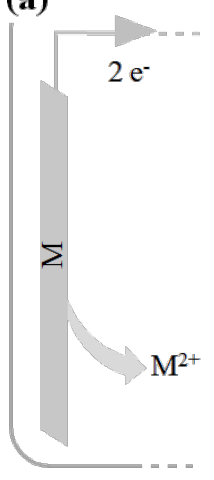

(b)

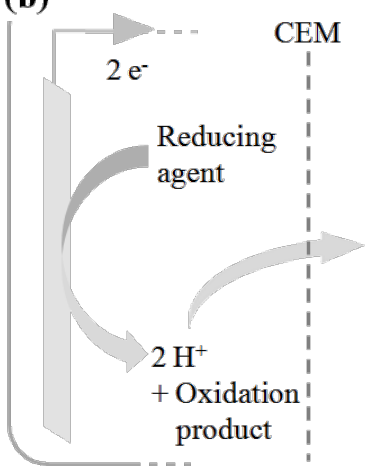

(c)

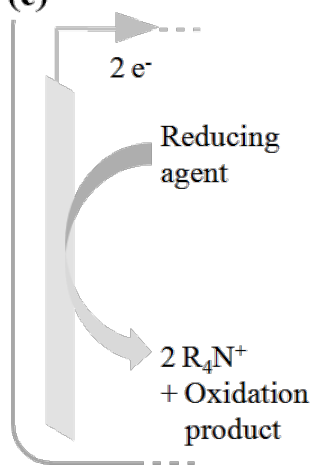

Cathodic reaction:

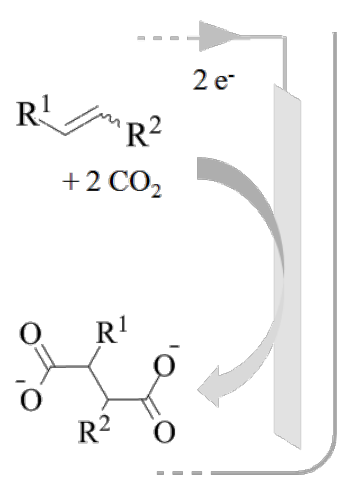

Scheme 6: Overview of electrocarboxylation setups using (a) a sacrificial anode, (b) an inert anode, generating protons, with a cation exchange membrane (CEM) and (c) an inert anode, releasing tetraalkylammonium cations. 
Electrocarboxylation reactions can either be conducted with a sacrificial anode, like magnesium or aluminum, or with an inert anode, like platinum or carbon. Most research has been focused on the fixation of $\mathrm{CO}_{2}$ using sacrificial anodes [38-40] (Scheme 6a). The higher oxidation potential of sacrificial anodes compared to that of the other reaction species makes this setup readily compatible with a simple undivided electrolysis cell, without a membrane separating the catholyte from the anolyte. This way high current densities can be obtained at relatively low potentials leading to minimized energy consumption. The absence of unwanted anodic reactions allows maintaining high current efficiencies without real difficulty. Furthermore, this counter electrode reaction delivers metal cations $\left(\mathrm{Mg}^{2+}\right.$, $\mathrm{Al}^{3+}$ ), which rapidly are coordinated by the carboxylate anions formed at the cathode. Finally, the corresponding metal carboxylates can be precipitated from organic solvents allowing easy product isolation. Alongside all the benefits that are associated with these sacrificial anodes, the gradual consumption of the anode material is a major drawback for industrial applications. Not only is it rather expensive to consume such large amounts of metal; it also strongly hinders the implementation of a continuous process. Additionally, in order to obtain the free acids, an acid hydrolysis step is required, complicating product purification, and generating a significant amount of waste. The potential industrial use of electrochemical $\mathrm{CO}_{2}$ fixation with sacrificial anodes should be found in fine chemical applications, preferably when the carboxylate salt can be used as such.

Considerable efforts have been made in investigating other electrocarboxylation systems. Replacing the sacrificial anode with a stable anode brings along several challenges. First of all, a counter electrode reaction must be identified, delivering counter cations to balance the charge of the carboxylate anions. The anodic reactant should be more easily oxidized than the other species present in the reaction mixture. The possible side product formed in this anodic reaction should either have no effect on the system, or be a useful reactant for the cathodic reaction. The direct formation of free carboxylic acids is a very interesting approach in this respect, minimizing the amount of process steps and waste (Scheme $6 \mathrm{~b}$ ). Protons produced at the anode, however, can have a detrimental effect on the electrocarboxylation efficiency, through cathodic formation of hydrogen, formic acid and other side products [41,42]. Hydrogen formation can be limited by usage of cathode materials with high hydrogen overvoltage like lead and mercury, or more environmentally friendly tantalum and zinc [43]. In order to minimize other side reactions a cation exchange membrane (CEM) is necessary, allowing different conditions in both compartments, giving a controlled supply of protons to the catholyte. Besides the implementation and maintenance costs of such a membrane, it also causes an elevated ohmic resistance between the elec- trodes decreasing the energy efficiency of the process. Moreover, most membranes have difficulty operating in organic solvents and under high pressure conditions, limiting operational conditions [44]. The anodic oxidation of more reduction stable tetraalkylammonium salts is another approach compatible with non-sacrificial anodes (Scheme 6c). Here, the released tetraalkylammonium cations function as counter ions for the cathodically formed carboxylate anions. If the corresponding oxidation products are not harmful for the cathodic reaction a simple undivided cell can be envisaged. However, this can also be considered as a sacrificial process, since the tetraalkylammonium salts are consumed during the reaction. But more importantly, in contrast to the use of a dissolving anode, this method allows a more efficient implementation of a continuous process.

The first reports on electrocarboxylation date back to the early 1960s with a patent of Loveland, demonstrating the dicarboxylation of 1,3-butadiene in a two-compartment cell with a mercury cathode and a platinum anode, giving a mixture of mono- and dicarboxylic acids. $\mathrm{CO}_{2}$ bubbling through a catholyte solution of $1 \mathrm{wt} \%$ water in DMF, saturated with butadiene, yielded up to $50 \%$ of 3-hexenedioic acid [45], a result which unfortunately was difficult to reproduce $[42,46]$. At that time, various substrates, like olefins, alkynes and aromatic ketones, have been electrocarboxylated in these divided cells [47]. Shortly after, sacrificial anodes made the use of a diaphragm obsolete, giving satisfactory product yields and current efficiencies in an undivided cell [38]. From this point on most of the research in the field of $\mathrm{CO}_{2}$ fixation was focused on this type of setup.

\section{Electrocarboxylation of conjugated dienes}

The electrochemical fixation of carbon dioxide in 1,3-butadiene has been extensively investigated because of the importance of adipic acid for the polymer industry. 1,3-Butadiene is widely available, not only from steam cracking, but increasingly from dehydrogenation of linear butenes. Dicarboxylation of 1,3-butadiene yields a mixture of 3-hexene-1,6-dioic acid isomers, which are only one hydrogenation step removed from adipic acid, a monomer of nylon $[41,42,44,48,49]$. The general mechanism of $\mathrm{CO}_{2}$ fixation in conjugated dienes is illustrated in Scheme 7. It is remarkable that only one electron is used per $\mathrm{CO}_{2}$ molecule which is incorporated, making this a very energy efficient approach. There are two possible pathways to reach the monocarboxylate radical anion intermediate: one in which first $\mathrm{CO}_{2}$ is reduced to a reactive $\mathrm{CO}_{2}{ }^{--}$radical anion, and another one in which a radical anion is formed from the alkene. It has been illustrated that both pathways may be operative at the same time $[49,50]$. Which mechanism is favored depends amongst other parameters mainly on the diene type [49-51], $\mathrm{CO}_{2}$ pressure [50] and cathode material [50]. 


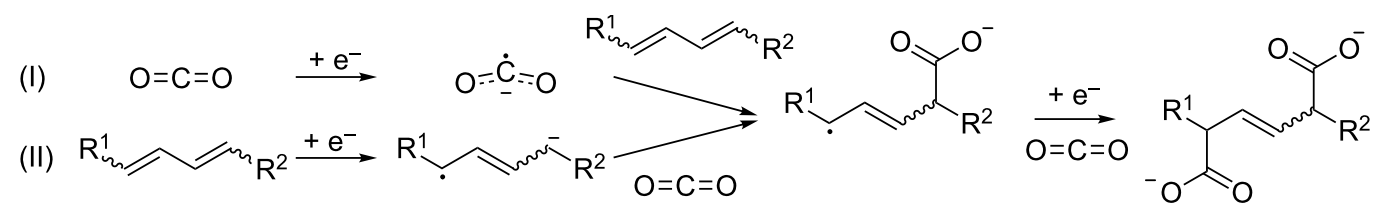

Scheme 7: General mechanism of the electrochemical dicarboxylation of conjugated dienes [49].

The different reactor setups used for the electrocarboxylation of 1,3-butadiene and the effect of the counter cation are illustrated in Table 1.

The different anodic reactions that have been used for the electrocarboxylation of 1,3-butadiene (Table 1) are illustrated in Scheme 8 . They are divided into three categories, with (a) the sacrificial anode dissolution, (b) the proton forming reactions and (c) the oxidations evolving other free cations.
In case a stable platinum anode is used, a $\mathrm{C} 5: \mathrm{C} 6: \mathrm{C} 10$ product mixture is formed, containing isomers of 3-pentenoic acid (C5), 3-hexenedioic acid (C6) and 3,7-decadienedioic acid (C10) (Table 1, entries 1-7). The product distribution is among other things influenced by the water and proton content in the reaction system. In a divided cell, in which the anolyte consists of $1 \% \mathrm{H}_{2} \mathrm{SO}_{4}$ in water, no $\mathrm{C} 6$ product is formed (Table 1, entry 1). Only in an anhydrous catholyte and anolyte, applying $\mathrm{MgO}$ in the anolyte as reducing agent, the carboxylation becomes more

\begin{tabular}{|c|c|c|c|c|c|c|c|}
\hline Entry & Anode & Reducing agent & $\mathrm{CEM}^{\mathrm{b}}$ & $\begin{array}{c}\text { Solvent } \\
\text { (catholyte - anolyte) }\end{array}$ & $\mathrm{C} 5: \mathrm{C} 6: \mathrm{C} 10^{\mathrm{C}}$ & $\eta^{\mathrm{d}}(\%)($ Yield $(\%))$ & Ref. \\
\hline $1^{\mathrm{e}}$ & $\mathrm{Pt}$ & $\mathrm{H}_{2} \mathrm{O}$ & Yes & $\mathrm{CH}_{3} \mathrm{CN}-\mathrm{H}_{2} \mathrm{O}^{\mathrm{f}}$ & $67: 0: 33$ & $18(11)$ & {$[41]$} \\
\hline $2^{g}$ & $\mathrm{Pt}$ & dry $\mathrm{MgO}$ & Yes & $\mathrm{CH}_{3} \mathrm{CN}-\mathrm{CH}_{3} \mathrm{CN}$ & $26: 58: 16$ & $31(21)$ & {$[41]$} \\
\hline $3^{g}$ & $\mathrm{Pt}^{\mathrm{h}}$ & $\mathrm{H}_{2}$ & No & $\mathrm{CH}_{3} \mathrm{CN}$ & $0: 0: 0$ & $0(0)$ & {$[42]$} \\
\hline $4^{g}$ & $\mathrm{Pt}^{\mathrm{h}}$ & $\mathrm{H}_{2}+$ dry $\mathrm{MgO}$ & No & $\mathrm{CH}_{3} \mathrm{CN}$ & $75: 25: 0$ & $3.7(-)$ & {$[42]$} \\
\hline $5^{\mathrm{g}, \mathrm{i}}$ & $\mathrm{Pt}^{\mathrm{h}}$ & $\mathrm{H}_{2} \mathrm{O}$ & Yes & $\mathrm{DMF}-\mathrm{H}_{2} \mathrm{O}^{\mathrm{f}}$ & $-:-:-$ & $3.4(-)$ & {$[42]$} \\
\hline $6^{g}$ & $\mathrm{Pt}$ & $\mathrm{NH}_{3}$ & No & $\mathrm{CH}_{3} \mathrm{CN}$ & $33: 54: 13$ & $5.8(-)$ & {$[42]$} \\
\hline $7^{\mathrm{j}}$ & $\mathrm{Pt}$ & $(\text { TEA })_{2}$ oxalate + TEA formate ${ }^{k}$ & No & $\mathrm{CH}_{3} \mathrm{CN}$ & $36: 52: 12$ & $39(98)$ & {$[44]$} \\
\hline $8^{l}$ & $\mathrm{Mg}$ & Anode & No & DMF & $2: 98: 0$ & $-(81)$ & {$[48]$} \\
\hline $9^{m}$ & $\mathrm{Al}$ & Anode & No & DMF & $0: 100: 0$ & $42(84)$ & [49] \\
\hline
\end{tabular}

${ }^{a}$ Reactions were performed in conditions presented in corresponding references; ${ }^{\mathrm{b}}$ cation exchange membrane; ${ }^{\mathrm{C}} \mathrm{C} 5: \mathrm{C} 6: \mathrm{C} 10=3-$-pentenoic acid:3hexenedioic acid:3,7-decadienedioic acid; ${ }^{d}$ total current efficiency; ${ }^{e}$ mercury cathode; ${ }^{\mathrm{f}} 1 \mathrm{wt} \% \mathrm{H}_{2} \mathrm{SO}_{4}$ solution; 9 lead cathode; ${ }^{\mathrm{h}}$ platinum hydrogen

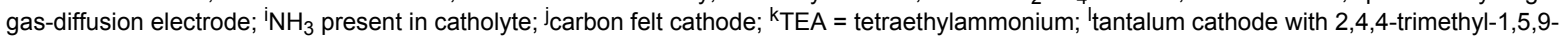
triazacyclododecene nickel(II) tetrafluoroborate mediator; ${ }^{m}$ nickel cathode.

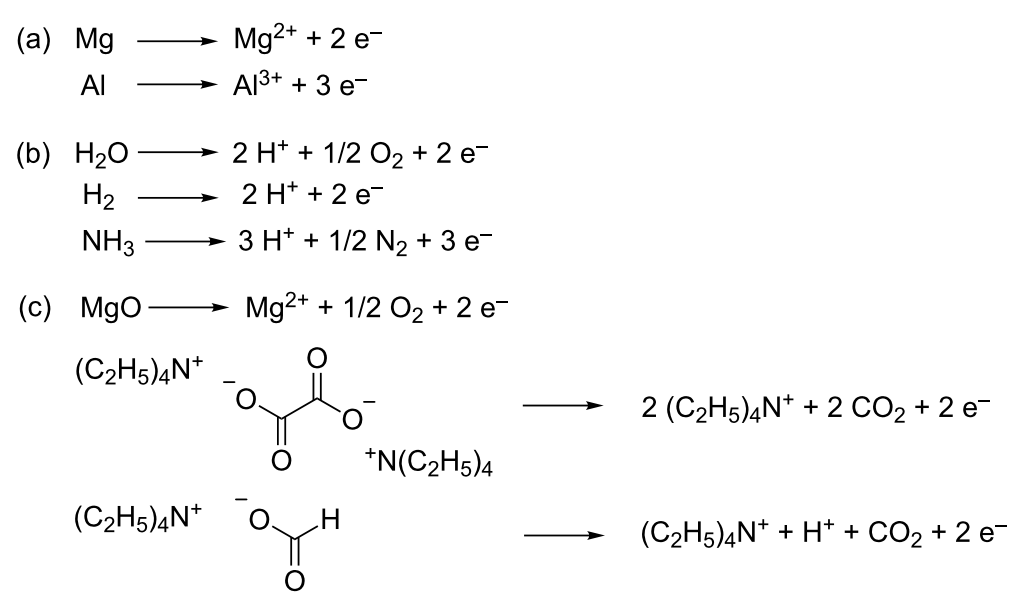


selective for C6, reaching appreciable current efficiencies (Table 1, entry 2). Furthermore, the presence of water in the catholyte decreases the total current efficiency, due to the formation of formic acid $[41,42]$. It must be noted that, when using an aqueous and organic solvent in anolyte and catholyte, respectively, the transfer of hydrated protons through the membrane will cause water to enter the catholyte. Protons in turn can also favor formic acid generation, but on top of that, they promote the $\mathrm{C} 5$ and $\mathrm{C} 10$ formation [41]. It must be noted that the presence of formic acid illustrates the existence of mechanism I (Scheme 7). When working in an undivided cell and using protons as sole counter cation through hydrogen oxidation in anhydrous conditions, only formic acid is produced (Table 1, entry 3) [42]. The latter stresses the effect of a cation exchange membrane in providing a controlled proton supply to the catholyte, minimizing cathodic formation of formic acid. In these electrosynthesis setups, in which protons are generated at the anode, cathodes with high hydrogen overpotential, like mercury and lead, are necessary to minimize current loss through hydrogen gas formation $[41,42]$.

The counter ion seems to have a significant influence on the fate of the cathodically formed $\mathrm{CO}_{2}{ }^{--}$radical anion. For carboxylation of a carbon skeleton to occur, this radical anion needs to react via the radical centered at its carbon atom. Grinberg et al. claim that metal or ammonium cations can cause a reversible migration of the negative charge between the carbon and oxygen atoms, allowing the $\mathrm{CO}_{2}{ }^{--}$radical anion to react with its $\mathrm{C}$-centered radical [42]. When this $\mathrm{CO}_{2}{ }^{--}$radical anion abstracts a proton from the solvent, proton migration from oxygen to carbon results in formation of a strong covalent $\mathrm{CH}$ bond, yielding a formyloxy radical, which is further reduced to a formate anion (Table 1, entry 3 ). In general terms, one can conclude that the electrocarboxylation of 1,3-butadiene is not efficiently performed in aqueous or protic media. $\mathrm{MgO}$ has been considered as an alternative cation source (Table 1, entry 4), but its solubility in organic solvents is low. Using ammonia as proton scavenger, with formation of ammonium counter cations, allows electrocarboxylation of 1,3-butadiene, and can increase the selectivity for the C6 product (Table 1, entries 5 and 6). The faradaic efficiencies, however, are rather low, hence, there has been a search to find alternative reducing agents.

Tetraethylammonium oxalate and formate salts appeared to be very promising for this purpose, fulfilling both the role of electrolyte and reducing agent. Tetraethylammonium cations have high reduction stability, while still possessing good ion pairing properties. The degree of delocalization of the positive charge is large enough to prevent cathodic reduction and small enough to allow a quick and stable interaction with the cathodically formed carboxylate anions. Furthermore, oxalate and formate are easily oxidized at a $\mathrm{Pt}$ anode, gradually releasing the tetraethylammonium cations. The combination of both salts in acetonitrile gives near quantitative yields of the C5:C6:C10 product mixture, with $\mathrm{C} 6$ as the main product (Table 1, entry 7) [44]. The anodic reaction produces $\mathrm{CO}_{2}$ which can directly be used as reactant at the cathode (Scheme 8), sustaining the atom economy of the process. This way, however, there is no net incorporation of gaseous $\mathrm{CO}_{2}$ into the organic substrate, but only net conversion of more energetic oxalate and formate. On top of that, it is important to realize that both the $\mathrm{MgO}$ and the tetraalkylammonium salts can also be considered as sacrificial reducing agents. Their advantage over sacrificial anodes, however, is an easier implementation in a continuous process. The anodic oxidation of formate generates one $\mathrm{CO}_{2}$ molecule and one proton, giving a controlled supply of protons to the cathode (Scheme 8). Conducting the electrocarboxylation with tetraethylammonium oxalate, without formate salts, increases the amount of C6 compared to C5 and C10 [44]. The use of acetonitrile as solvent is ideal when working in an undivided cell, thanks to its adequate oxidation stability and high dielectric constant. Anhydrous conditions and the easier oxidation of oxalate and formate, at a Pt anode, compared to butadiene and the cathodically generated carboxylates, make the use of a membrane redundant, enabling the use of a simple undivided cell [44]. Moreover, the use of membranes in non-aqueous or aprotic environments is unsatisfactory as they become poorly conducting [44]. This procedure was patented and extended to various other substrates, like activated olefins, imines, carbonyl and halogen compounds, and other anions like an azide, which forms inert $\mathrm{N}_{2}$ upon oxidation [52].

Eventually the electrocarboxylation of 1,3-butadiene was also conducted with sacrificial anodes, resulting in a high selectivity for the C6 product (Table 1, entries 8 and 9) [48,49]. Working under anhydrous conditions allows using another range of cathode materials, such as nickel, without being limited by the hydrogen overvoltage. The cathode metal has a large effect on the product distribution, acting as a catalyst $[44,49]$. Secondly, the absence of a membrane allowed the use of high $\mathrm{CO}_{2}$ pressures, pushing the selectivity towards the C6 product, completely eliminating $\mathrm{C} 10$ formation [49]. The abovementioned benefits of sacrificial anode systems have lead to the electrocarboxylation of various other conjugated dienes [49$51,53,54]$. In order to increase the selectivity for the C6 product, dissolved nickel and iron redox mediators have been used $[48,53,54]$. The need for such organometallic complexes could be eliminated by direct electrocarboxylation on nickel or stainless steel cathode surfaces $[49,50]$. Substrates with an internal conjugated system appear to be less reactive towards $\mathrm{CO}_{2}$ fixation, due to steric hindrance and the presence of electron 
donating substituents $[49,51]$. However, working at atmospheric $\mathrm{CO}_{2}$ pressures and at lower current densities allows effectively performing the double carboxylation of internal conjugated double bonds in open chains. This way, conjugated linoleic acids could be dicarboxylated with a yield approaching $80 \%$ at current efficiencies of over $50 \%$, opening the reactant scope to other renewable dienes [50]. The occurrence of mechanism I (Scheme 7) was illustrated via the formation of oxalic acid, the $\mathrm{CO}_{2}$ dimerization product [50]. Additional insight in the carboxylation mechanism was gained by comparing the reactivity of 1,3-cyclohexadiene with a mixture of 2,4-hexadiene isomers. The fixed cyclic conformation of 1,3-cyclohexadiene increases its reactivity towards $\mathrm{CO}_{2}$ fixation, explained by a higher adsorption strength on the cathode surface. This suggests that dienes undergo carboxylation according to mechanism II while adsorbed on the surface, combined with mechanism I (Scheme 7). Moreover it was shown that diene configuration has a strong stereoelectronic effect on the rate of the dicarboxylation, with the $Z, Z$-configuration being the most reactive one [50].

\section{Electrocarboxylation of olefins and alkynes}

Many reports have been published on the electrocarboxylation of olefins and alkynes [55-74]. Most research has been done using a setup with a sacrificial magnesium or aluminum anode. The general mechanism of alkyne electrocarboxylation to a 1,4dicarboxylated product is shown in Scheme 9. It is highly similar to the mechanism for electrocarboxylation of olefins. In these reactions a high selectivity for dicarboxylation can be achieved.

Alkynes and olefins react according to similar pathways, although a separate mechanism has been proposed for selective monocarboxylation of alkynes using nickel mediators, usually with bipyridine or $N, N, N^{\prime}, N^{\prime}, N^{\prime \prime}$-pentamethyldiethylenetriamine ligands [55-60]. These organometallic complexes have also proven their value in increasing the carboxylation efficiency of alkenes, without including a specific selectivity for the monocarboxylic acid [56]. Monocarboxylation can readily occur as a side reaction when a small amount of protons are present in the reaction mixture, or through a proton/hydrogen radical abstraction from the reaction medium. The triple bond of alkynes is more active towards carboxylation than the olefin double bond [56]; furthermore, terminal alkynes are more reactive than internal alkynes [56-58], both leading to highly selective $\mathrm{CO}_{2}$ fixation. The selectivity towards the dicarboxylation product can be significantly increased by working at higher $\mathrm{CO}_{2}$ pressures $[61,66]$, although an optimum must be found to minimize oxalic acid formation at high $\mathrm{CO}_{2}$ pressures by electrodimerization of $\mathrm{CO}_{2}$ [72]. Under rigorously anhydrous conditions, the dicarboxylation product of alkynes, shown in Scheme 9, can be transformed to a maleic anhydride [61,62]. Alkynes are rather reactive as such; olefins can be rendered more reactive by introduction of electron withdrawing groups $[68-71,73,74]$. Thus ethyl cinnamate was electrocarboxylated in $78 \%$ yield to give a mixture of mono- and dicarboxylated product (Scheme 10) [70].

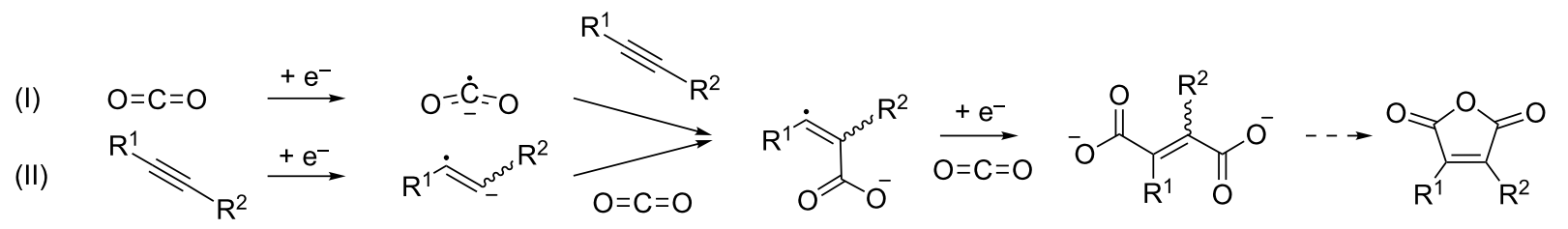

Scheme 9: General mechanism for electrocarboxylation of alkynes.

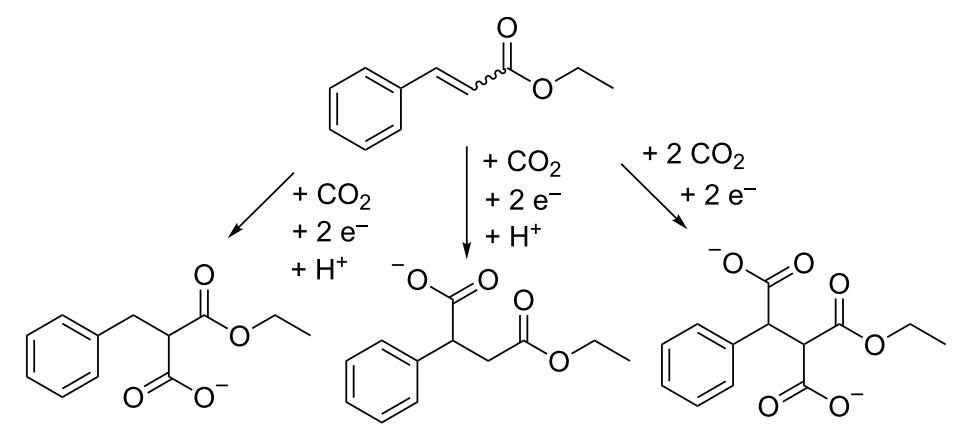


Activated olefins like dimethyl maleate and acrylonitrile have also been reacted in a setup with a stable anode utilizing tetraethylammonium oxalate, formate or azide salts as the reductant [52].

\section{Electrocarboxylation of ketones, aldehydes and imines}

As is the case for conjugated dienes, olefins and alkynes, two possible pathways exist for electrocarboxylation of carbonyl and imine compounds. One starts with $\mathrm{CO}_{2}$ reduction; another starts with reduction of the substrate (Scheme 11). The second route is considered as the predominant one [75]. In case the carbonyl or imine compound is reduced first, the negative charge may reside either on the carbon or on the heteroatom. This results in a first $\mathrm{CO}_{2}$ fixation on the carbon or on the heteroatom, depending on the electron-withdrawing/electrondonating properties of the substituents $\mathrm{R}^{1}$ and $\mathrm{R}^{2}$. In both cases, a second electron reduction in presence of $\mathrm{CO}_{2}$ yields a carboxylate intermediate with an additional carbonate or carbamate group. The latter is converted to the corresponding $\alpha$-hydroxy acid or to an $\alpha$-amino acid after acid hydrolysis in the product work-up [75-77].
An alternative mechanism has been proposed for aliphatic aldehydes, in which not $\alpha$-hydroxy acids are formed but in which $\mathrm{CO}_{2}$ is incorporated on the $\alpha$-carbon according to Scheme 12 [78]. Here, the reduced aldehyde abstracts a proton from the $\alpha$-carbon of an unreacted aldehyde.

The electrocarboxylation of ketones was first described by Wawzonek, converting benzophenone and acetophenone to benzylic acid and 2-hydroxy-2-phenylpropionic acid, respectively [79]. This offers an electrochemical route for several commercially relevant $\alpha$-aryl propionic acids, used as nonsteroidal anti-inflammatory drugs (NSAIDs) [80]. Therefore, the electrocarboxylation of aromatic ketones with sacrificial anodes has been extensively investigated [75-77,81-98]. Some researchers focused on replacing toxic and volatile organic solvents with ionic liquids [81-83]. Their negligible vapor pressure, large electrochemical window, good intrinsic conductivity and high $\mathrm{CO}_{2}$ solubility make them interesting solvents for electrochemical $\mathrm{CO}_{2}$ valorization [81-83,99-101]. Under similar conditions, ketones are carboxylated with higher selectivity for the $\alpha$-hydroxy acid compared to aldehydes, and especially compared to aliphatic aldehydes, like acetaldehyde, which give
(I)

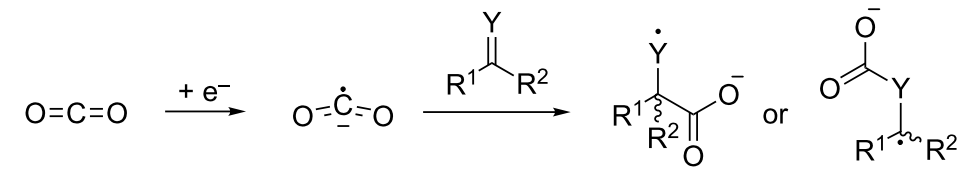

(II)<smiles></smiles><smiles>[R7]C([Y])[R7]</smiles>

(A)<smiles>O=C1CCCCCO1</smiles>

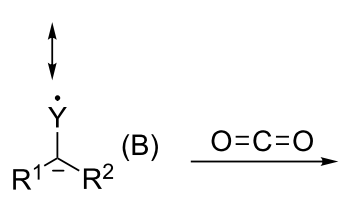<smiles></smiles>

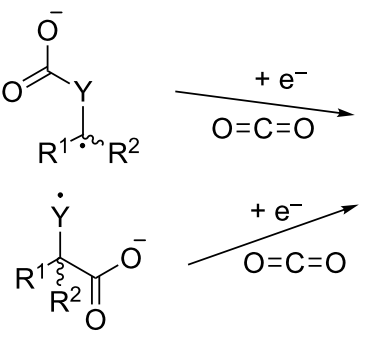

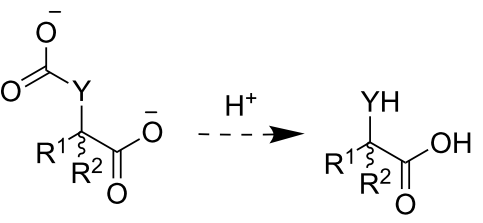

Scheme 11: General electrocarboxylation mechanism for carbonyl compounds $(Y=O)$ and imines $(Y=N H)[75-77]$.

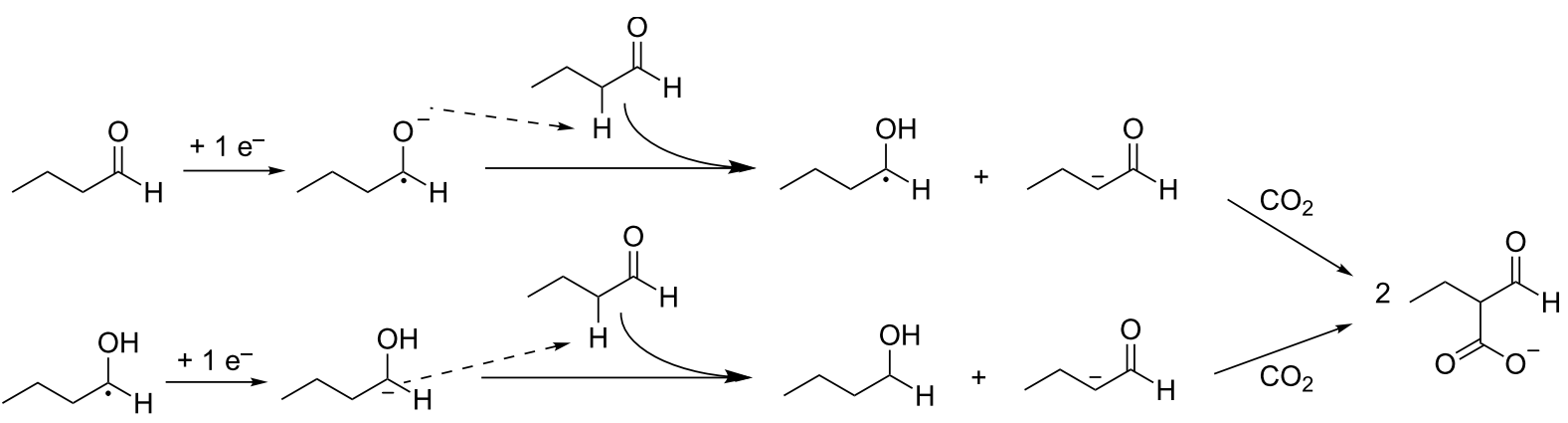


very poor yields [84]. Since carbonyl compounds have the tendency to accept an electron more easily than $\mathrm{CO}_{2}$, the reaction mixture contains a lot of carbonyl radical anions, which can form vicinal diol dimers (pinacols) as side product $[75,76,83]$. The ratio of $\mathrm{CO}_{2}$ to substrate is of great importance in obtaining a high selectivity for the $\alpha$-hydroxy acid products. Working at high $\mathrm{CO}_{2}$ pressures and low carbonyl concentrations gives the highest faradaic efficiencies, minimizing pinacol formation. The presence of protons drastically increases the amount of dimerization product and favors the hydrogenation of the carbonyl group to the alcohol $[75,76,82,91]$. The cathode material again plays an important role in the electrocarboxylation of carbonyl compounds. Toxic lead cathodes [85] and expensive platinum cathodes [87] can easily be replaced by better performing stainless steel [90] and nickel $[75,89]$. Concerning the reactivity of carbonyl compounds, it has been demonstrated that the carboxylation rate of benzophenones is decreased by electron donating substituents [90]. The pharmaceutical value of the electrocarboxylation of aromatic ketones to NSAIDs has lead to a significant number of patents using a sacrificial anode [9295]. Since enantioselectivity is crucial for anti-inflammatory drugs, research has also been performed on the enantioselective electrocarboxylation of aromatic ketones, using chiral alkaloids [96-98].

The most important semi-industrial scale electrocarboxylation processes are related to the synthesis of these NSAIDs. The $\alpha$-hydroxy acid is an intermediate, still requiring a chemical hydrogenation to obtain the desired product. 2-Acetyl-6methoxynaphthalene (AMN) can be converted to hydroxynaproxen $(\mathrm{HN})$, a precursor of naproxen (Scheme 13) [85,86]. Although yields up to $90 \%$ were obtained in a $1 \mathrm{~L}$ flow reactor, the switch to a $75 \mathrm{~L}$ system was accompanied by leaks and instrument problems resulting in a low yield (58\%) and current efficiency (30\%) [86].

Besides carbonyl compounds, imines have also shown value as substrates for electrocarboxylation, namely in the synthesis of non-natural amino acids [102-108]. A semi-industrial setup was designed for the electrocarboxylation of benzalaniline (Scheme 14). Scale up was done in a filter press type cell with flow distribution, which is commercially available. The electrodes are pressed together with a PTFE coated glass fibre net between them. This way, the inter-electrode gap remains constant during consumption of the anode. In a $2 \mathrm{~L}$ solution with $200 \mathrm{~g}$ of reactant, a product yield of $85 \%$ and a current efficiency of $80 \%$ were obtained [105].

The electrocarboxylation of aromatic ketones was also conducted with stable electrodes as shown in Scheme 15 $[94,95]$. In these patents $p$-isobutylacetophenone is carboxylated to hydroxyibuprofen, which is readily hydrogenolyzed to ibuprofen. A nafion membrane is used, allowing a selective passage of protons and tetraalkylammonium cations from the anolyte to the catholyte. Cyclohexene is added to the anolyte to scavenge the anodically formed bromine. A current efficiency of up to $90 \%$ was reached with a copper cathode and graphite anode. The method appeared also suitable for the synthesis of other NSAIDs like naproxen, cicloprofen, isoprofen, flurbiprofen, fenoprofen and carprofen.

The electrocarboxylation of aliphatic aldehydes was also patented, namely for the production of 2-hydroxy-4-methylmercaptobutyric acid (MHA) by electrochemical carboxylation of 3-methylmercaptopropionaldehyde (MMP), with both a sacrificial anode [109] and a stable anode [110,111] (Scheme 16). The

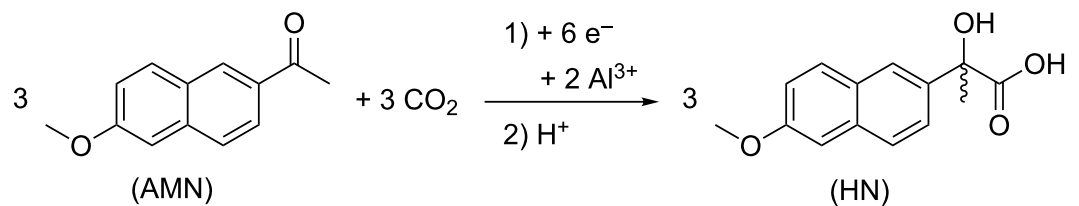

Scheme 13: Electrocarboxylation of $A M N$ to $H N$ using a sacrificial aluminum anode [86]. 


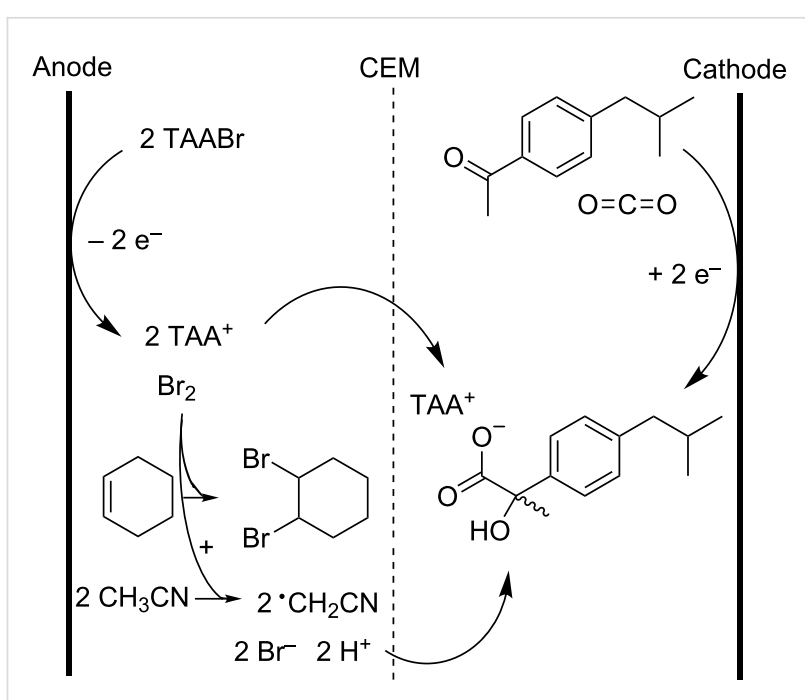

Scheme 15: Electrocarboxylation of $p$-isobutylacetophenone with stable electrodes [94,95].

system, using the stable electrodes, can be extended to aldehydes, ketones and imines.

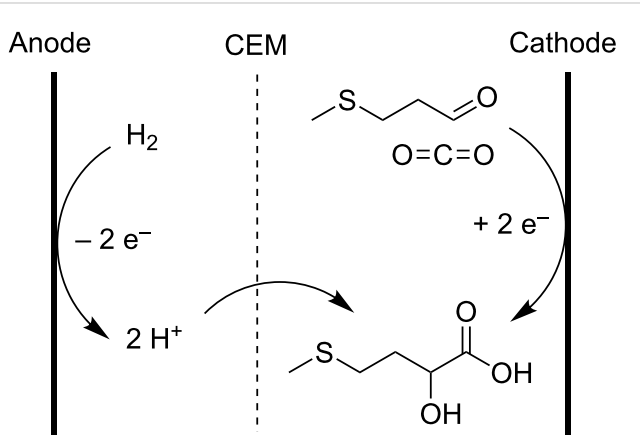

Scheme 16: Electrochemical carboxylation of MMP to MHA $[110,111]$

MHA is an industrial scale feed additive, which is conventionally prepared using cyanides. In the proposed setup for the electrocatalytic preparation of MHA, a boron-doped diamond coated permeable cathode and Pt coated permeable anode rest directly on the cation exchange membrane to decrease ohmic resistance by the membrane, minimizing the required voltage. Hydrogen, supplied to the anolyte gives protons, which gradually enter the catholyte to form the free carboxylic acids. Both anolyte and catholyte are based on DMF. Unfortunately, no yields or current efficiencies higher than $30 \%$ were obtained [111].

There are also examples in which aromatic ketones and imines are electrocarboxylated in an undivided cell with stable anode. $\mathrm{CO}_{2}$ fixation in acetophenone was done in good yields in an undivided cell using a quaternary ammonium oxalate as an elec- trolyte and a sacrificial reducing agent $[52,94,95,112,113]$. Benzalanilines were carboxylated electrochemically with $79 \%$ faradaic yield, using an oxalate electrolyte [52].

\section{Electrocarboxylation of organic halides}

Numerous reports have been published on the electrocarboxylation of organic halides [114-146]. In a first step, a one electron reduction causes a halide anion to dissociate, forming a reactive radical. The latter undergoes a second reduction in the presence of $\mathrm{CO}_{2}$, yielding a monocarboxylate anion (Scheme 17) $[122,124-126,128]$.

$$
\mathrm{R}^{1-} \mathrm{X} \stackrel{+\mathrm{e}^{-}}{\longrightarrow} \mathrm{R}^{1} \cdot+\mathrm{X}^{-} \underset{\mathrm{O}=\mathrm{C}=\mathrm{O}}{\stackrel{+\mathrm{e}^{-}}{\longrightarrow}} \mathrm{R}^{1} \bigwedge_{\mathrm{O}}^{\mathrm{O}^{-}}+\mathrm{X}^{-}
$$

Scheme 17: General mechanism for electrocarboxylation of alkyl halides [122,124-126,128].

The first reactions reported were conducted in a divided cell, giving only moderate yields [114,115]. A drastic increase in efficiency was obtained by employing sacrificial anodes [116], especially magnesium anodes $[117,118]$. The cathode material is again of great importance, with silver and platinum giving the highest carboxylation selectivity [119-125]. Redox mediators allow working at a less negative cathodic potential, which results in a better energy efficiency and a more selective $\mathrm{CO}_{2}$ fixation [128]. The most common redox mediators are organometallic nickel [129-131], palladium [132] and cobalt complexes [133-137].

Similar to what was mentioned above for aromatic ketones, benzylic chlorides can also be converted to 2-arylpropionic acids (Scheme 18), with applications in the pharmaceutical industry, mainly as NSAIDs. Here too, some articles described the use of ionic liquids as solvent for electrocarboxylation reactions, in order to increase the safety and efficiency of the process $[120,122]$.

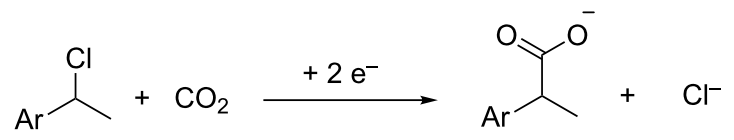

Scheme 18: Electrocarboxylation of benzylic chlorides as synthesis route for NSAIDs.

The industrial potential of this reaction has been assessed in several pilot applications, for example, using a setup with a sacrificial anode. In a $400 \mathrm{~L}$ reactor, a narrow and constant interelectrode gap was maintained in time and space, avoiding 
an ohmic drop during consumption of the anode material. A polyethylene grid is placed between the electrodes, allowing the anode to press down on the cathode by its own weight. A good agitation is obtained by pumping the reaction mixture through the cell [138]. Unfortunately, industrial production was not developed because of difficulties in the purification of the product, arising from the presence of impurities generated by the degradation of the solvent [139]. Another pilot scale experiment, conducted for the production of NSAIDs, uses a stable graphite anode in an undivided cell. The anodic reaction is the oxidation of lithium oxalate, giving yields up to $85 \%$ of 2 -phenylpropionic acid [140]. The same group also investigated a setup in which a metal powder, like zinc, is oxidized at the anode, giving similar results [141].

The electrocarboxylation of organic halides can also be considered as an alternative dechlorination pathway for chlorobenzenes [122] and polychloromethanes [142]. While the synthesis of halogenated reagents is rather hazardous, the electrocarboxylation of organic halides is an interesting method to revalue waste products, like for example carbon tetrachloride, a toxic liquid, causing ozone depletion. In an undivided cell and acetonitrile as solvent, tri- and dichloroacetic acid are formed with current efficiencies between 50 and $60 \%$. The exact anodic reaction(s), however, are not really specified. Oxidation of chloride, which itself originates in the $\mathrm{CCl}_{4}$ reactant, likely results in partial chlorination of the acetonitrile solvent, releasing protons which in turn cause the formation of chloroform by attacking the cathodically formed carbanions [143].

An undivided electrosynthesis setup with stable anode can also be used for $\mathrm{CO}_{2}$ fixation in other aliphatic halides. The anodic oxidation of tetraethylammonium oxalate is used in the electrocarboxylation of 1-bromo-2-methylpentane, which is almost quantitatively converted into 3-methylhexanoic acid [52]. The electrocarboxylation of 1,4-dibromo-2-butene is another reaction for which a stable anode and an undivided cell were proposed. The goal here is to form 3-hexenedioic acid, a precursor of adipic acid, although very poor yields and current efficiencies were obtained. Besides 1,4-dibromo-2-butene, 1,3butadiene is added in the one-compartment cell to capture the bromine generated at the anode, forming the reactant (Scheme 19). The low yields are caused by debromodimerization and oligomerization [144].

A significant effort has been devoted to efficiently produce cyanoacetic acid through $\mathrm{CO}_{2}$ fixation in chloroacetonitrile, as an alternative for the hazardous synthesis via alkali metal cyanides $[137,145,146]$. Derivatives of cyanoacetic acid are precious starting materials in pharmaceutical and agrochemical synthesis [137]. When the anodic reaction is the oxidation of a

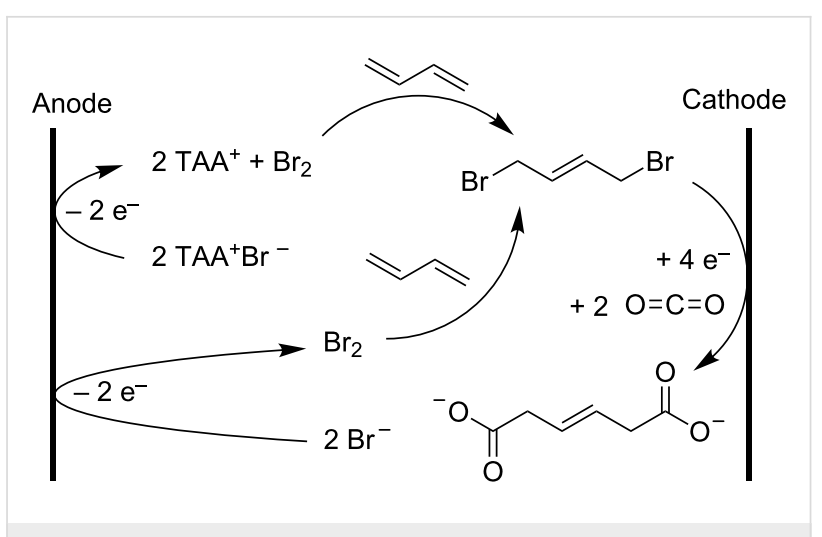

Scheme 19: Electrocarboxylation of 1,4-dibromo-2-butene [144]

halide, lower current efficiencies can be attributed to a successive oxidation and reduction of respectively halides and halonium species. Therefore, the use of a membrane or glass frit can be interesting to minimize this effect. However, in a divided cell, the electrocarboxylation of chloroacetonitrile to cyanoacetic acid still appeared to give higher current efficiencies when using a sacrificial anode [146]. The major downside in carboxylating organic halides is the release of halides in the system, which can moreover induce a significant number of side reactions in a non-sacrificial setup, and which is in any case disadvantageous for the atom economy.

\section{Innovative electrocarboxylation of other substrates}

Besides the electrocarboxylation of chloroacetonitrile, $\mathrm{CO}_{2}$ can also be incorporated electrocatalytically in acetonitrile itself. Such reaction was successfully conducted in a two-compartment cell divided by a medium porosity glass frit (Scheme 20). This is an interesting alternative for the conventional synthesis of cyanoacetic acid, which is carried out by the reaction of chloroacetic acid and alkaline cyanides [147-149].

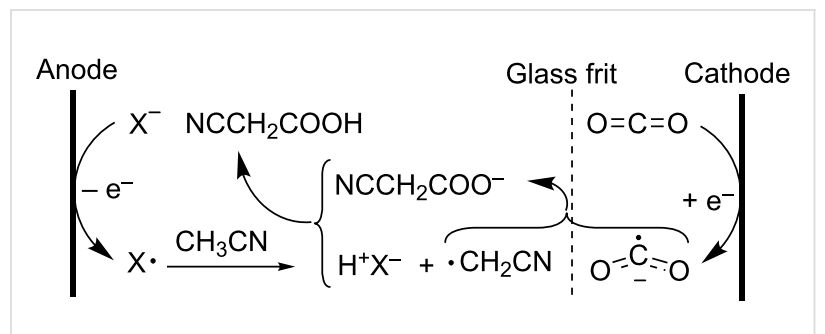

Scheme 20: Convergent paired electrosynthesis of cyanoacetic acid, with $\mathrm{X}^{-}=\mathrm{F}_{4} \mathrm{~B}^{-}, \mathrm{ClO}_{4}^{-}, \mathrm{HSO}_{4}^{-}, \mathrm{Cl}^{-}, \mathrm{Br}^{-}$[147].

The electrocarboxylation of acetonitrile to cyanoacetic acid is an example of a convergent paired electrosynthesis, meaning that two different substrates undergo either oxidation or reduction to afford products that react among themselves to generate 
a single product. Cyanomethyl radicals are formed by anodic oxidation of the supporting electrolyte anion followed by hydrogen radical abstraction from the acetonitrile solvent. These cyanomethyl radicals are then coupled to the $\mathrm{CO}_{2}{ }^{-}$ radical anion, forming cyanoacetic acid after protonation. The authors claim that the product is solely formed in the anolyte after $\mathrm{CO}_{2}{ }^{--}$transport from the catholyte to the anolyte, although transport from cyanomethyl radicals to the catholyte is not excluded. However, product formation through cathodic reduction of acetonitrile is ruled out properly, since no cyanoacetic acid was formed when using a cation-exchange membrane. Since most of the product is present in the anolyte, current yields are rather low (24\%). Moreover, the electrolyte anion and the cyanoacetic acid product have similar oxidation potentials. On top of that, some halogenation of the solvent to chloroacetonitrile was observed as a side reaction [147]. This reaction setup was also tested with propionitrile, butyronitrile, benzyl chloride and toluene in the anolyte compartment. Adjacent functional groups weaken $\mathrm{C}-\mathrm{H}$ bonds, yielding relatively stable radicals, in turn resulting in selective $\mathrm{CO}_{2}$ fixation [150].

Another patented system uses electrogenerated bases to deprotonate a weakly acidic hydrocarbon group forming anions which are carboxylated in the presence of $\mathrm{CO}_{2}$. Meanwhile, proton scavengers remove protons released from the anodic regeneration of the base precursors as shown in Scheme 21 [151].

The electrogenerated bases are redox mediators, used as catalysts in the carboxylation process. The net reaction can be written as follows:

$\mathrm{RH}+\mathrm{CO}_{2}+$ scavenger $\rightarrow \mathrm{RCOO}^{-}+$innocuous scavenger reaction product.
The base precursor should be more easily electroreduced than the weakly acidic hydrocarbon group and carbon dioxide, and should not undergo a nucleophilic attack by either the hydrocarbon anion or the electrogenerated base. Therefore, the base precursor should be sterically hindered at or near the site(s) where reduction will occur. The electrogenerated base must be a strong enough Brønsted base to deprotonate the weakly acidic hydrocarbon group. Ethenetetracarboxylate tetraesters are typical base precursors, suited for the electrocarboxylation of $N$-alkyldiglycolimides (Scheme 22). This process provides a feasible route to methoxymethane-1,1,1'-tricarboxylate salts, which are excellent detergent builders. The reaction should be carried out in strictly anhydrous conditions, since water is a stronger acid than the weakly acidic hydrocarbons employed herein. Electrogenerated bromine is used to regenerate the base precursor. Via a radical bromination, followed by a nucleophilic elimination under alkaline conditions, the alkane is oxidized to the alkene base precursor. These alkaline conditions and the four electron withdrawing ethoxy carbonyl groups $\left(\mathrm{R}^{1}\right)$, prevent further bromination of the acquired double bond. Sodium carbonate is a suitable proton scavenger, providing the required alkalinity and being a convenient source of sodium ions. Crown ethers are added to dissolve the alkali metal salts in the organic solvent system. After reaction, anolyte and catholyte are filtered and base precursor and conjugate acid of electrogenerated base must be transferred to the other compartment. In this divided cell a yield of $85 \%$ for product (A) could be obtained (Scheme 22). In an undivided setup however, lower yields and current efficiencies were observed [151].

Oxalic acid is another carboxylic acid which can be formed through electrocarboxylation, namely of $\mathrm{CO}_{2}$ itself. This complexing agent has applications in cleaning industry, dyeing processes and metallurgy [152]. Besides its easy synthesis

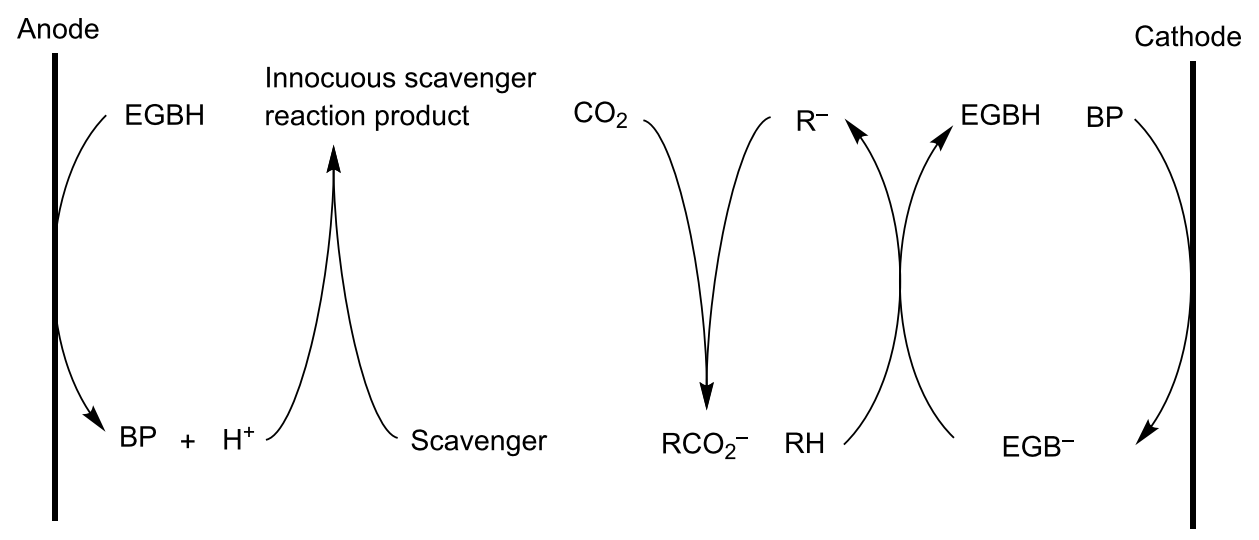

Scheme 21: General scheme of carboxylation of weak acidic hydrocarbons with electrogenerated bases. RH: weakly acidic hydrocarbon; BP: base precursor; EGB' ${ }^{-}$: electrogenerated base; EGBH: conjugate acid of electrogenerated base [151]. 


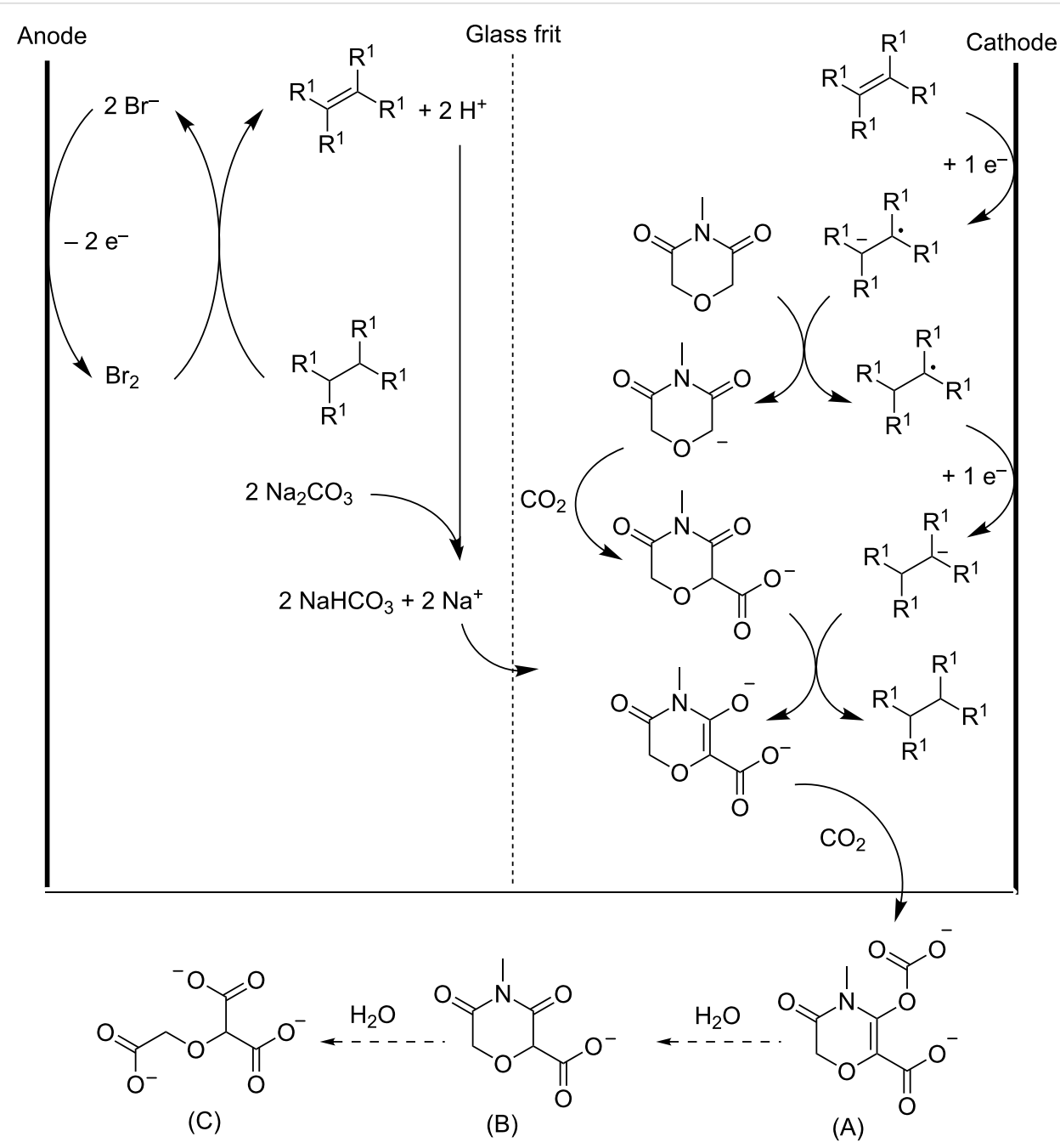

Scheme 22: Electrocarboxylation of $N$-methyldiglycolimide to methoxymethane-1,1,1'-tricarboxylate precursors. $\mathrm{R}^{1}$ : ethoxycarbonyl [151].

under anhydrous conditions in a cell with sacrificial anode, it can also be produced in a stable electrode setup, with current efficiencies over $50 \%$ (Scheme 23) [153]. In the catholyte an organic solvent is used while the anolyte consists of an aqueous $\mathrm{NaCl}$ solution. The anodically formed chlorine gas is continuously removed from the anolyte. A cation exchange membrane allows the selective transport of sodium cations to the catholyte. The sodium oxalate that is produced precipitates from the solution. A downside of this setup is the gradual transfer of water from the aqueous anolyte to the organic catholyte, this way steadily lowering the selectivity of the process [153].

\section{Conclusion}

Electrochemical reduction is an efficient approach to activate thermodynamically stable $\mathrm{CO}_{2}$ under relatively mild and safe conditions. Electrocarboxylation allows the production of valuable carboxylic acids, through incorporation of $\mathrm{CO}_{2}$ in a wide range of organic chemicals. This way, polymer building blocks

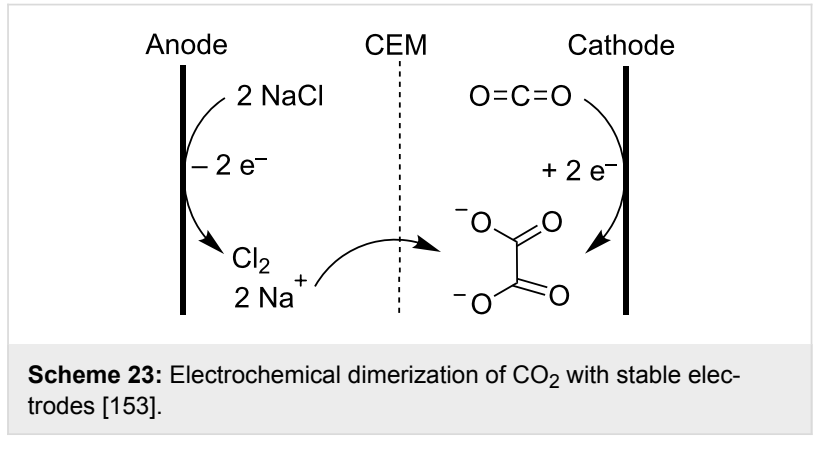

are produced from conjugated dienes, NSAIDs can easily be obtained from aromatic ketones and benzylic halides, and various other interesting applications are possible. Despite the vast amount of papers and patents on this subject, no industrial applications have emerged yet; only a couple of pilot plant scale processes have been demonstrated. The sustainable and efficient formation of carboxylic acids from carbon dioxide 
presents many intriguing challenges. The choice of reactor setup, electrode type and reaction pathway, not only affects the implementation cost but also determines operational characteristics like process continuity, atom economy and current efficiency. The shortcomings illustrated in this review emphasize the need for more innovative pathways to invent even more efficient and sustainable electrocarboxylation reactions.

\section{Acknowledgements}

This research is funded by the Industrieel Onderzoeksfonds KU Leuven (project IKP/10/005). We are grateful to KU Leuven for support through the Methusalem grant CASAS, in the frame of IAP 7 Supramolecular Chemistry and Catalysis.

\section{References}

1. Proceedings of " $\mathrm{CO}_{2}$ Emission from Fuels Combustion: Highlights 2012”, October, 2012, Paris, France.

http://www.iea.org/publications/freepublications/publication/CO2emissi onfromfuelcombustionhighlightsMarch2013.pdf (accessed October 27, 2014).

2. Hoekman, S. K.; Broch, A.; Robbins, C.; Purcell, R. Int. J. Greenhouse Gas Control 2010, 4, 44-50. doi:10.1016/j.ijggc.2009.09.012

3. Wang, W.; Wang, S.; Ma, X.; Gong, J. Chem. Soc. Rev. 2011, 40, 3703-3727. doi:10.1039/c1cs15008a

4. Ion, A.; Parvulescu, V.; Jacobs, P.; de Vos, D. Appl. Catal., A 2009, 363, 40-44. doi:10.1016/j.apcata.2009.04.036

5. Darensbourg, D. J.; Horn, A., Jr.; Moncada, A. I. Green Chem. 2010, 12, 1376-1379. doi:10.1039/c0gc00136h

6. Yang, Z.-Z.; Zhao, Y.-N.; He, L.-N.; Gao, J.; Yin, Z.-S. Green Chem. 2012, 14, 519-527. doi:10.1039/c2gc16039k

7. Tomishige, K.; Yasuda, H.; Yoshida, Y.; Nurunnabi, M.; Li, B.; Kunimori, K. Green Chem. 2004, 6, 206-214. doi:10.1039/b401215a

8. Ion, A.; Parvulescu, V.; Jacobs, P.; De Vos, D. Green Chem. 2007, 9, 158-161. doi:10.1039/b612403h

9. Ion, A.; Van Doorslaer, C.; Parvulescu, V.; Jacobs, P.; De Vos, D. Green Chem. 2008, 10, 111-116. doi:10.1039/b711197e

10. Guyer, A. Process for the manufacture of urea. U.S. Patent $2,854,482$, Sept 30, 1958.

11. Krase, N. W.; Gaddy, V. L. Ind. Eng. Chem. 1922, 14, 611-615. doi:10.1021/ie50151a009

12. Aresta, M.; Dibenedetto, A. Dalton Trans. 2007, 2975-2992. doi:10.1039/b700658f

13. Moore, E. R.; McDonald, D. C.; Willner, J.; Briggs, R. L. Carbonation of alkali metal phenates. U.S. Patent 4,171,453, Oct 16, 1979.

14. Kolbe, H. Ann. Chem. Pharm. 1860, 113, 125-127. doi:10.1002/jlac. 18601130120

15. Schmitt, R. J. Prakt. Chem. 1885, 31, 397-411. doi:10.1002/prac. 18850310130

16. Hunt, S. E.; Jones, J. I.; Lindsey, A. S.; Killoh, D. C.; Turner, H. S. J. Chem. Soc. 1958, 3152-3160. doi:10.1039/jr9580003152

17. Markovic, Z.; Engelbrecht, J. P.; Markovic, S. Z. Naturforsch. 2002, 57, 812-818

18. Rahim, M. A.; Matsui, Y.; Matsuyama, T.; Kosugi, Y. Bull. Chem. Soc. Jpn. 2003, 76, 2191-2195. doi:10.1246/bcsj.76.2191
19. Kosugi, Y.; Imaoka, Y.; Gotoh, F.; Rahim, M. A.; Matsui, Y.; Sakanishi, S. Org. Biomol. Chem. 2003, 1, 817-821. doi:10.1039/b210793g

20. Marković, Z.; Marković, S.; Manojlović, N.; Predojević-Simović, J. J. Chem. Inf. Model. 2007, 47, 1520-1525. doi:10.1021/ci700068b

21. Finnegan, R. A.; Altschuld, J. W. J. Organomet. Chem. 1967, 9 193-204. doi:10.1016/S0022-328X(00)83721-3

22. Quirk, R. P.; Yin, J.; Fetters, L. J.; Kastrup, R. V. Macromolecules 1992, 25, 2262-2267. doi:10.1021/ma00034a030

23. Ebert, G. W.; Juda, W. L.; Kosakowski, R. H.; Ma, B.; Dong, L.; Cummings, K. E.; Phelps, M. V. B.; Mostafa, A. E.; Luo, J. J. Org. Chem. 2005, 70, 4314-4317. doi:10.1021/jo047731s

24. Correa, A.; Martín, R. Angew. Chem., Int. Ed. 2009, 48, 6201-6204. doi:10.1002/anie.200900667

25. Jitaru, M. J. Univ. Chem. Technol. Metall. 2007, 42, 333-344.

26. Schäfer, H. J. C. R. Chim. 2011, 14, 745-765. doi:10.1016/j.crci.2011.01.002

27. Agarwal, A. S.; Zhai, Y.; Hill, D.; Sridhar, N. ChemSusChem 2011, 4, 1301-1310. doi:10.1002/cssc.201100220

28. Ganesh, I. Renewable Sustainable Energy Rev. 2014, 31, 221-257. doi:10.1016/j.rser.2013.11.045

29. Cook, R. L.; MacDuff, R. C.; Sammells, A. F. J. Electrochem. Soc. 1988, 135, 1320-1326. doi:10.1149/1.2095972

30. Olah, G. A.; Prakash, G. K. S.; Goeppert, A. J. Am. Chem. Soc. 2011, 133, 12881-12898. doi:10.1021/ja202642y

31. Sequeira, C. A. C.; Santos, D. M. F. J. Braz. Chem. Soc. 2009, 20, 387-406. doi:10.1590/S0103-50532009000300002

32. Danly, D. E. J. Electrochem. Soc. 1984, 131, 435C-442C. doi:10.1149/1.2115324

33. Matthews, M. A. Pure Appl. Chem. 2001, 73, 1305-1308. doi:10.1351/pac200173081305

34. Pütter, H.; Hannebaum, H. Preparation of phthalides. U.S. Patent 6,063,256, May 16, 2000.

35. Frontana-Uribe, B. A.; Little, R. D.; Ibanez, J. G.; Palma, A.; Vasquez-Medrano, R. Green Chem. 2010, 12, 2099-2119. doi:10.1039/c0gc00382d

36. Doherty, A. P.; Christensen, P. A.; Hamnett, A.; Scott, K. J. Electroanal. Chem. 1995, 386, 39-44. doi:10.1016/0022-0728(94)03816-L

37. Li, J.; Hu, X.; Su, Y.; Li, Q. Chem. Eng. Sci. 2007, 62, 6784-6793. doi:10.1016/j.ces.2007.02.021

38. Silvestri, G.; Gambino, S.; Filardo, G. Acta Chem. Scand. 1991, 45, 987-992. doi:10.3891/acta.chem.scand.45-0987

39. Tokuda, M. J. Nat. Gas Chem. 2006, 15, 275-281. doi:10.1016/S1003-9953(07)60006-1

40. Silvestri, G.; Scialdone, O. Recent Scientific and Technological Developments in Electrochemical Carboxylation Based on Carbon Dioxide. In Carbon dioxide as Chemical feedstock; Aresta, M., Ed.; Wiley-VCH: Weinheim, Germany, 2010; pp 317-334. doi:10.1002/9783527629916.ch12

41. van Tilborg, W. J. M.; Smit, C. J. Recl. Trav. Chim. Pays-Bas 1981, 100, 437-438. doi:10.1002/recl.19811001113

42. Grinberg, V. A.; Koch, T. A.; Mazin, V. M.; Mysov, E. I.; Sterlin, S. R. Russ. Chem. Bull. 1999, 48, 294-299. doi:10.1007/BF02494552

43. Scott, K. Dev. Chem. Eng. Miner. Process. 1993, 1, 71-117. doi:10.1002/apj.5500010202

44. Pletcher, D.; Tietje Girault, J. J. Appl. Electrochem. 1986, 16, 791-802. doi:10.1007/BF01006524

45. Loveland, J. W. Electrolytic production of acyclic carboxylic acids from hydrocarbons. U.S. Patent 3,032,489, May 1, 1962. 
46. Neikam, W. C. Electrolytic preparation of carboxylic acids. U.S. Patent 3,344,045, Sept 26, 1967.

47. Tyssee, D. A.; Wagenknecht, J. H.; Baizer, M. M.; Chruma, J. L. Tetrahedron Lett. 1972, 13, 4809-4812. doi:10.1016/S0040-4039(01)94435-1

48. Bringmann, J.; Dinjus, E. Appl. Organomet. Chem. 2001, 15, 135-140. doi:10.1002/1099-0739(200102)15:2<135::AID-AOC108>3.0.CO;2-L

49. Li, C.-H.; Yuan, G.-Q.; Ji, X.-C.; Wang, X.-J.; Ye, J.-S.; Jiang, H.-F. Electrochim. Acta 2011, 56, 1529-1534. doi:10.1016/j.electacta.2010.06.057

50. Zhang, K.; Xiao, Y.; Lan, Y.; Zhu, M.; Wang, H.; Lu, J. Electrochem. Commun. 2010, 12, 1698-1702. doi:10.1016/j.elecom.2010.09.028

51. Matthessen, R.; Fransaer, J.; Binnemans, K.; De Vos, D. E. RSC Adv. 2013, 3, 4634-4642. doi:10.1039/c3ra00129f

52. van Tilborg, W. J. M.; Smit, C. J.; Engels, R. A process for the electroreductive preparation of organic compounds. Eur. Patent 0,028,430, May 13, 1981.

53. Ballivet-Tkatchenko, D.; Folest, J.-C.; Tanji, J. Appl. Organomet. Chem. 2000, 14, 847-849. doi:10.1002/1099-0739(200012)14:12<847::AID-AOC78>3.0.CO;2-7

54. Dérien, S.; Clinet, J.-C.; Duñach, E.; Périchon, J. Tetrahedron 1992, 48, 5235-5248. doi:10.1016/S0040-4020(01)89021-9

55. Labbé, E.; Duñach, E.; Périchon, J. J. Organomet. Chem. 1988, 353, C51-C56. doi:10.1016/0022-328X(88)80330-9

56. Duñach, E.; Périchon, J. J. Organomet. Chem. 1988, 352, 239-246. doi:10.1016/0022-328X(88)83038-9

57. Duñach, E.; Dérien, S.; Périchon, J. J. Organomet. Chem. 1989, 364, C33-C36. doi:10.1016/0022-328X(89)87156-6

58. Dérien, S.; Duñach, E.; Périchon, J. J. Am. Chem. Soc. 1991, 113, 8447-8454. doi:10.1021/ja00022a037

59. Dérien, S.; Clinet, J.-C.; Duñach, E.; Périchon, J. J. Org. Chem. 1993, 58, 2578-2588. doi:10.1021/jo00061a038

60. Saito, S.; Nakagawa, S.; Koizumi, T.; Hirayama, K.; Yamamoto, Y. J. Org. Chem. 1999, 64, 3975-3978. doi:10.1021/jo982443f

61. Yuan, G.-Q.; Jiang, H.-F.; Lin, C. Tetrahedron 2008, 64, 5866-5872. doi:10.1016/j.tet.2008.04.053

62. Li, C.; Yuan, G.; Jiang, H. Chin. J. Chem. 2010, 28, 1685-1689. doi:10.1002/cjoc.201090285

63. Köster, F.; Dinjus, E.; Duñach, E. Eur. J. Org. Chem. 2001, 2507-2511. doi:10.1002/1099-0690(200107)2001:13<2507::AID-EJOC2507>3.0.C O;2-P

64. Senboku, H.; Komatsu, H.; Fujimura, Y.; Tokuda, M. Synlett 2001, 418-420. doi:10.1055/s-2001-11417

65. Wang, H.; Lin, M.-Y.; Fang, H.-J.; Chen, T.-T.; Lu, J.-X. Chin. J. Chem. 2007, 25, 913-916. doi:10.1002/cjoc.200790177

66. Yuan, G.-Q.; Jiang, H.-F.; Lin, C.; Liao, S.-J. Electrochim. Acta 2008, 53, 2170-2176. doi:10.1016/j.electacta.2007.09.023

67. Gambino, S.; Gennaro, A.; Filardo, G.; Silvestri, G.; Vianello, E. J. Electrochem. Soc. 1987, 134, 2172-2175. doi:10.1149/1.2100846

68. Orsini, M.; Feroci, M.; Sotgiu, G.; Inesi, A. Org. Biomol. Chem. 2005, 3, 1202-1208. doi:10.1039/b500570a

69. Wang, H.; Zhang, G.; Liu, Y.; Luo, Y.; Lu, J. Electrochem. Commun. 2007, 9, 2235-2239. doi:10.1016/j.elecom.2007.06.031

70. Wang, H.; Du, Y.-F.; Lin, M.-Y.; Zhang, K.; Lu, J.-X. Chin. J. Chem. 2008, 26, 1745-1748. doi:10.1002/cjoc.200890316
71. Lin, M.-Y.; Wang, H.; Zhang, A.-J.; Zhang, G.-R.; Lu, J.-X. Chin. J. Org. Chem. 2008, 28, 1572-1577. http://sioc-journal.cn/Jwk_yjhx/EN/abstract/abstract337403.shtml

72. Gambino, S.; Silvestri, G. Tetrahedron Lett. 1973, 14, 3025-3028. doi:10.1016/S0040-4039(01)96310-5

73. Tyssee, D. A.; Baizer, M. M. J. Org. Chem. 1974, 39, 2819-2823. doi:10.1021/jo00933a001

74. Tyssee, D. A. Electrolytic monocarboxylation of activated olefins. U.S. Patent 4,028,201, June 7, 1977.

75. Yuan, G.; Li, Z.; Jiang, H. Chin. J. Chem. 2009, 27, 1464-1470. doi:10.1002/cjoc.200990246

76. Scialdone, O.; Amatore, C.; Galia, A.; Filardo, G. J. Electroanal. Chem. 2006, 592, 163-174. doi:10.1016/j.jelechem.2006.04.009

77. Pletcher, D.; Slevin, L. J. Chem. Soc., Perkin Trans. 2 1996, 217-220. doi:10.1039/p29960000217

78. Doherty, A. P. Electrochim. Acta 2002, 47, 2963-2967. doi:10.1016/S0013-4686(02)00196-2

79. Wawzonek, S.; Gundersen, A. J. Electrochem. Soc. 1960, 107, 537-540. doi:10.1149/1.2427738

80. Rieu, J.-P.; Boucherle, A.; Cousse, H.; Mouzin, G. Tetrahedron 1986, 42, 4095-4131. doi:10.1016/S0040-4020(01)87634-1

81. Zhao, S.-F.; Wu, L.-X.; Wang, H.; Lu, J.-X.; Bond, A. M.; Zhang, J. Green Chem. 2011, 13, 3461-3468. doi:10.1039/c1gc15929a

82. Zhao, S.-F.; Horne, M.; Bond, A. M.; Zhang, J. Green Chem. 2014, 16, 2242-2251. doi:10.1039/c3gc42404a

83. Feng, Q.; Huang, K.; Liu, S.; Yu, J.; Liu, F. Electrochim. Acta 2011, 56, 5137-5141. doi:10.1016/j.electacta.2011.03.061

84. Silvestri, G.; Gambino, S.; Filardo, G. Tetrahedron Lett. 1986, 27, 3429-3430. doi:10.1016/S0040-4039(00)84814-5

85. Chan, A. S. C.; Huang, T. T.; Wagenknecht, J. H.; Miller, R. E. J. Org. Chem. 1995, 60, 742-744. doi:10.1021/jo00108a047

86. Datta, A. K.; Marron, P. A.; King, C. J. H.; Wagenknecht, J. H. J. Appl. Electrochem. 1998, 28, 569-577. doi:10.1023/A:1003289800341

87. Lateef, S. K.; Raju, R. R.; Mohan, S. K.; Reddy, S. J. Synth. Commun. 2006, 36, 31-36. doi:10.1080/00397910500328811

88. Zhang, L.; Xiao, L. P.; Niu, D. F.; Luo, Y. W.; Lu, J. X. Chin. J. Chem. 2008, 26, 35-38. doi:10.1002/cjoc.200890034

89. Zhang, K.; Wang, H.; Wu, L.; Zhang, J.; Lu, J. Chin. J. Chem. 2010, 28, 509-513. doi:10.1002/cjoc.201090104

90. Zhao, S.-F.; Wang, H.; Lan, Y.-C.; Liu, X.; Lu, J.-X.; Zhang, J. J. Electroanal. Chem. 2012, 664, 105-110. doi:10.1016/j.jelechem.2011.11.001

91. Scialdone, O.; Galia, A.; Isse, A. A.; Gennaro, A.; Sabatino, M. A.; Leone, R.; Filardo, G. J. Electroanal. Chem. 2007, 609, 8-16. doi:10.1016/j.jelechem.2007.02.014

92. Silvestri, G.; Gambino, S.; Filardo, G. Process for the electrocarboxylation of carbonyl compounds, for producing alpha-hydoxycarboxylic acids. U.S. Patent 4,708,780, Nov 24, 1987.

93. Maspero, F.; Piccolo, O.; Romano, U.; Gambino, S. New process for the preparation of 2-aryl-propionic acids. U.S. Patent 5,089,661, Feb 18, 1992.

94. Wagenknecht, J. H. Electrochemical carboxylation of p-isobutylacetophenone. U.S. Patent 4,582,577, April 15, 1986.

95. Wagenknecht, J. H. Electrochemical carboxylation of p-isobutylacetophenone and other aryl ketones. U.S. Patent 4,601,797, July 22, 1986. 
96. Zhang, K.; Wang, H.; Zhao, S.-F.; Niu, D.-F.; Lu, J.-X. J. Electroanal. Chem. 2009, 630, 35-41. doi:10.1016/j.jelechem.2009.02.013

97. Zhao, S.-F.; Zhu, M.-X.; Zhang, K.; Wang, H.; Lu, J.-X. Tetrahedron Lett. 2011, 52, 2702-2705. doi:10.1016/j.tetlet.2011.03.076

98. Chen, B.-L.; Tu, Z.-Y.; Zhu, H.-W.; Sun, W.-W.; Wang, H.; Lu, J.-X. Electrochim. Acta 2014, 116, 475-483. doi:10.1016/j.electacta.2013.11.001

99. Doherty, A. P.; Diaconu, L.; Marley, E.; Spedding, P. L.; Barhdadi, R.; Troupel, M. Asia-Pac. J. Chem. Eng. 2012, 7, 14-23. doi:10.1002/apj.529

100.Barrosse-Antle, L. E.; Compton, R. G. Chem. Commun. 2009 3744-3746. doi:10.1039/b906320j

101.Snuffin, L. L.; Whaley, L. W.; Yu, L. J. Electrochem. Soc. 2011, 158, F155-F158. doi:10.1149/1.3606487

102. Weinberg, N. L.; Hoffmann, A. K.; Reddy, T. B. Tetrahedron Lett. 1971, 12, 2271-2274. doi:10.1016/S0040-4039(01)96837-6

103. Hess, U. Z. Chem. 1980, 20, 148-149.

104. Hess, U.; Thiele, R. J. Prakt. Chem. 1982, 324, 385-399. doi:10.1002/prac.19823240306

105. Silvestri, G.; Gambino, S.; Filardo, G.; Tedeschi, F. J. Appl. Electrochem. 1989, 19, 946-948. doi:10.1007/BF01007947

106.Koshechko, V. G.; Titov, V. E.; Bondarenko, V. N.; Pokhodenko, V. D. J. Fluorine Chem. 2008, 129, 701-706. doi:10.1016/j.jluchem.2008.06.010

107. Titov, V. E.; Bondarenko, V. N.; Koshechko, V. G.; Pokhodenko, V. D. Theor. Exp. Chem. 2010, 46, 8-13. doi:10.1007/s11237-010-9113-6

108.Wang, H.; Zhang, K.; Chen, B. L.; Li, R. N.; Zhao, J. Q.; Lu, J. X. Int. J. Electrochem. Sci. 2011, 6, 1720-1729.

109.Lehmann, T.; Schneider, R.; Weckbecker, C.; Dunach, E.; Olivera, S. Process for the production of 2-hydroxy-4-methylmercaptobutyric acid. U.S. Patent 6,475,370, Nov 5, 2002.

110.Reufer, C.; Hateley, M.; Lehmann, T.; Weckbecker, C.; Sanzenbacher, R.; Bilz, J. Process for the preparation of a-substituted carboxylic acids from the series comprising $\alpha$-hydroxycarboxylic acids and n-substituted-a-aminocarboxylic acids. U.S. Patent 7,332,067, Feb 19, 2008.

111.Hoppe, C.-F.; Nordschild, A.; Jakob, H.; Weckbecker, C.; Roth, P.; Imad, M. Preparing alpha-substituted carboxylic acids, comprises cathodic carboxylation of a compound in a conducting salt and an organic solvent containing catholyte with carbon dioxide at a diamond cathode layer. Ger. Patent 102,011,078,468, Jan 3, 2013.

112. Engels, R.; Smit, C. J.; van Tilborg, W. J. M. Angew. Chem., Int. Ed. Engl. 1983, 22, 492-493. doi:10.1002/anie.198304921

113. Ikeda, Y.; Manda, E. Chem. Lett. 1984, 13, 453-454. doi:10.1246/cl.1984.453

114.Baizer, M. M.; Chruma, J. L. J. Org. Chem. 1972, 37, 1951-1960. doi:10.1021/jo00977a020

115.Wawzonek, S.; Shradel, J. M. J. Electrochem. Soc. 1979, 126, 401-403. doi:10.1149/1.2129051

116.Silvestri, G.; Gambino, S.; Filardo, G.; Gulotta, A. Angew. Chem., Int. Ed. Engl. 1984, 23, 979-980. doi:10.1002/anie.198409791

117.Sock, O.; Troupel, M.; Périchon, J. Tetrahedron Lett. 1985, 26, 1509-1512. doi:10.1016/S0040-4039(00)98538-1

118. Heintz, M.; Sock, O.; Saboureau, C.; Périchon, J. Tetrahedron 1988 , 44, 1631-1636. doi:10.1016/S0040-4020(01)86724-7
119. Isse, A. A.; Gennaro, A. Chem. Commun. 2002, 2798-2799. doi:10.1039/b206746c

120.Gennaro, A.; Sánchez-Sánchez, C. M.; Isse, A. A.; Montiel, V. Electrochem. Commun. 2004, 6, 627-631. doi:10.1016/j.elecom.2004.04.019

121.Isse, A. A.; Ferlin, M. G.; Gennaro, A. J. Electroanal. Chem. 2005, 581, 38-45. doi:10.1016/j.jelechem.2005.04.007

122. Aishah, A. J.; Hartini, M. A.; Normala, S.; Norhuda, A. M.; Hanis, H. H. N.; Razif, H. M.; Sugeng, T. J. Nat. Gas Chem. 2007, 16, 273-277. doi:10.1016/S1003-9953(07)60059-0

123.Niu, D.-F.; Xiao, L.-P.; Zhang, A.-J.; Zhang, G.-R.; Tan, Q.-Y.; Lu, J.-X. Tetrahedron 2008, 64, 10517-10520. doi:10.1016/j.tet.2008.08.093

124.Niu, D.; Zhang, J.; Zhang, K.; Xue, T.; Lu, J. Chin. J. Chem. 2009, 27, 1041-1044. doi:10.1002/cjoc.200990174

125.Lan, Y.-C.; Wang, H.; Wu, L.-X.; Zhao, S.-F.; Gu, Y.-Q.; Lu, J.-X. J. Electroanal. Chem. 2012, 664, 33-38. doi:10.1016/j.jelechem.2011.10.011

126. Hiejima, Y.; Hayashi, M.; Uda, A.; Oya, S.; Kondo, H.; Senboku, H.; Takahashi, K. Phys. Chem. Chem. Phys. 2010, 12, 1953-1957. doi:10.1039/b920413j

127.Feng, Q.; Huang, K.; Liu, S.; Wang, X. Electrochim. Acta 2010, 55, 5741-5745. doi:10.1016/j.electacta.2010.05.010

128. Scialdone, O.; Galia, A.; Silvestri, G.; Amatore, C.; Thouin, L.; Verpeaux, J.-N. Chem. - Eur. J. 2006, 12, 7433-7447. doi:10.1002/chem.200501499

129. Troupel, M.; Rollin, Y.; Périchon, J.; Fauvarque, J. F. Nouv. J. Chim. 1981, 2, 621-625.

130. Amatore, C.; Jutand, A. J. Am. Chem. Soc. 1991, 113, 2819-2825. doi:10.1021/ja00008a003

131. Gennaro, A.; Isse, A. A.; Maran, F. J. Electroanal. Chem. 2001, 507, 124-134. doi:10.1016/S0022-0728(01)00373-4

132.Amatore, C.; Jutand, A.; Khalil, F.; Nielsen, M. F. J. Am. Chem. Soc. 1992, 114, 7076-7085. doi:10.1021/ja00044a018

133. Folest, J.-C.; Duprilot, J.-M.; Périchon, J.; Robin, Y.; Devynck, J. Tetrahedron Lett. 1985, 26, 2633-2636. doi:10.1016/S0040-4039(00)98122-X

134.Isse, A. A.; Gennaro, A.; Vianello, E. J. Chem. Soc., Dalton Trans. 1996, 1613-1618. doi:10.1039/dt9960001613

135.Zheng, G.; Stradiotto, M.; Li, L. J. Electroanal. Chem. 1998, 453, 79-88. doi:10.1016/S0022-0728(98)00173-9

136.Chung, W.-H.; Guo, P.; Wong, K.-Y.; Lau, C.-P. J. Electroanal. Chem. 2000, 486, 32-39. doi:10.1016/S0022-0728(00)00125-X

137.Fabre, P.-L.; Reynes, O. Electrochem. Commun. 2010, 12, 1360-1362. doi:10.1016/j.elecom.2010.07.020

138. Chaussard, J.; Troupel, M.; Robin, Y.; Jacob, G.; Juhasz, J. P. J. Appl. Electrochem. 1989, 19, 345-348. doi:10.1007/BF01015234

139. Chanfreau, S.; Cognet, P.; Camy, S.; Condoret, J.-S. J. Supercrit. Fluids 2008, 4, 156-162. doi:10.1016/j.supflu.2008.04.003

140.Fauvarque, J. F.; Jutand, A.; Francois, M. J. Appl. Electrochem. 1988, 18, 109-115. doi:10.1007/BF01016213

141.Fauvarque, J. F.; De Zelicourt, Y.; Amatore, C.; Jutand, A. J. Appl. Electrochem. 1990, 20, 338-340. doi:10.1007/BF01033614

142. Olloqui-Sariego, J. L.; Molina, V. M.; González-Arjona, D.; Roldán, E.; Domínguez, M. J. Electrochem. Soc. 2010, 157, E64-E68. doi:10.1149/1.3299365

143. Olloqui-Sariego, J. L.; Molina, V. M.; González-Arjona, D.; Roldán, E.; Domínguezz, M. J. Electrochem. Soc. 2008, 155, E157-E161. doi:10.1149/1.2971028 
144.Grinberg, K. A.; Koch, T. A.; Mazin, E. M.; Mysov, E. I.; Sterlin, S. R. Russ. Chem. Bull. 1997, 46, 1560-1564. doi:10.1007/BF02502939 145.Scialdone, O.; Galia, A.; Belfiore, C.; Filardo, G.; Silvestri, G. Ind. Eng. Chem. Res. 2004, 43, 5006-5014. doi:10.1021/ie034275+ 146. Isse, A. A.; Gennaro, A. J. Electrochem. Soc. 2002, 149, D113-D117. doi:10.1149/1.1490358

147.Batanero, B.; Barba, F.; Sánchez-Sánchez, C. M.; Aldaz, A. J. Org. Chem. 2004, 69, 2423-2426. doi:10.1021/jo0358473

148.Scialdone, O.; Sabatino, M. A.; Galia, A.; Filardo, G.; Silvestri, G. J. Electroanal. Chem. 2008, 614, 175-178. doi:10.1016/j.jelechem.2007.11.012

149. Tyssee, D. A. Electrolytic carboxylation of acetonitrile and alpha-substituted acetonitriles. U.S. Patent 3,945,896, March 23 , 1976.

150. Otero, M. D.; Batanero, B.; Barba, F. Tetrahedron Lett. 2006, 47, 2171-2173. doi:10.1016/j.tetlet.2006.01.113

151. Hallcher, R. C.; Baizer, M. M.; White, D. A. Electrolytic carboxylation of carbon acids via electrogenerated bases. U.S. Patent 4,072,583, Feb 7, 1978.

152. Riemenschneider, W.; Tanifuji, M. Oxalic acid. In Ullmann's Encyclopedia of Industrial Chemistry; Elvers, B.; Noethe, H., Eds.; Wiley-VCH: Weinheim, Germany, 2002. doi:10.1002/14356007.a18_247

153.Goodridge, F.; Presland, G. J. Appl. Electrochem. 1984, 14, 791-796. doi:10.1007/BF00615269

\section{License and Terms}

This is an Open Access article under the terms of the Creative Commons Attribution License

(http://creativecommons.org/licenses/by/2.0), which permits unrestricted use, distribution, and reproduction in any medium, provided the original work is properly cited.

The license is subject to the Beilstein Journal of Organic Chemistry terms and conditions:

(http://www.beilstein-journals.org/bjoc)

The definitive version of this article is the electronic one which can be found at:

$\underline{\text { doi:10.3762/bjoc. } 10.260}$ 